\title{
Reactivation of tectonics, crustal underplating, and uplift after 60 Myr of passive subsidence, Raukumara Basin, Hikurangi- Kermadec fore arc, New Zealand: Implications for global growth and recycling of continents
}

\author{
Rupert Sutherland, ${ }^{1}$ Vaughan Stagpoole, ${ }^{1}$ Christopher Uruski, ${ }^{1}$ Callum Kennedy, ${ }^{2}$ \\ Daniel Bassett, ${ }^{3}$ Stuart Henrys, ${ }^{1}$ Martin Scherwath, ${ }^{4}$ Heidrun Kopp, ${ }^{4}$ Brad Field, ${ }^{1}$ \\ Suzannah Toulmin, ${ }^{1}$ Daniel Barker, ${ }^{1}$ Stephen Bannister, ${ }^{1}$ Fred Davey, ${ }^{1}$ \\ Timothy Stern, ${ }^{3}$ and Ernst R. Flueh ${ }^{4}$ \\ Received 5 July 2008; revised 13 May 2009; accepted 9 July 2009; published 28 October 2009.
}

[1] We use seismic reflection and refraction data to determine crustal structure, to map a fore-arc basin containing $12 \mathrm{~km}$ of sediment, and to image the subduction thrust at $35 \mathrm{~km}$ depth. Seismic reflection megasequences within the basin are correlated with onshore geology: megasequence X, Late Cretaceous and Paleogene marine passive margin sediments; megasequence $\mathrm{Y}$, a $\sim 10,000 \mathrm{~km}^{3}$ submarine landslide emplaced during subduction initiation at $22 \mathrm{Ma}$; and megasequence $Z$, a Neogene subduction margin megasequence. The Moho lies at $17 \mathrm{~km}$ beneath the basin center and at $35 \mathrm{~km}$ at the southern margin. Beneath the western basin margin, we interpret reflective units as deformed Gondwana fore-arc sediment that was thrust in Cretaceous time over oceanic crust $7 \mathrm{~km}$ thick. Raukumara Basin has normal faults at its western margin and is uplifted along its eastern and southern margins. Raukumara Basin represents a rigid fore-arc block $>150 \mathrm{~km}$ long, which contrasts with widespread faulting and large Neogene vertical axis rotations farther south. Taper of the western edge of allochthonous unit $\mathrm{Y}$ and westward thickening and downlap of immediately overlying strata suggest westward or northwestward paleoslope and emplacement direction rather than southwestward, as proposed for the correlative onshore allochthon. Spatial correlation between rock uplift of the eastern and southern basin margins with the intersection between Moho and subduction thrust leads us to suggest that crustal underplating is modulated by fore-arc crustal thickness. The trench

\footnotetext{
${ }^{1}$ GNS Science, Lower Hutt, New Zealand.

${ }^{2}$ New Zealand Ministry of Economic Development, Wellington, New Zealand.

${ }^{3}$ Environment and Earth Sciences, School of Geography, Victoria University of Wellington, Wellington, New Zealand.

${ }^{4}$ Leibniz Institute of Marine Sciences at University of Kiel (IFMGEOMAR), Kiel, Germany.
}

Copyright 2009 by the American Geophysical Union. 0278-7407/09/2008TC002356\$12.00 slope has many small extensional faults and lacks coherent internal reflections, suggesting collapse of indurated rock, rather than accretion of $>1 \mathrm{~km}$ of sediment from the downgoing plate. The lack of volcanic intrusion east of the active arc, and stratigraphic evidence for the broadening of East Cape Ridge with time, suggests net fore-arc accretion since $22 \mathrm{Ma}$. We propose a cyclical fore-arc kinematic: rock moves down a subduction channel to near the base of the crust, where underplating drives rock uplift, oversteepens the trench slope, and causes collapse toward the trench and subduction channel. Cyclical rock particle paths led to persistent trench slope subsidence during net accretion. Existing global estimates of fore-arc loss are systematically too high because they assume vertical particle paths. Citation: Sutherland, R., et al. (2009), Reactivation of tectonics, crustal underplating, and uplift after $60 \mathrm{Myr}$ of passive subsidence, Raukumara Basin, Hikurangi-Kermadec fore arc, New Zealand: Implications for global growth and recycling of continents, Tectonics, 28, TC5017, doi:10.1029/2008TC002356.

\section{Introduction}

[2] The Raukumara Plain lies adjacent to northeast North Island, New Zealand, and is part of the fore-arc region of the Hikurangi-Kermadec subduction zone (Figure 1). Marine geophysical surveys carried out during the 1970s and 1980s revealed sediment cover, but it was not until a multichannel seismic reflection (MCS) line was acquired in 1990 (line OGS90) that a thick sedimentary fill reaching $\sim 13 \mathrm{~km}$ thickness was identified in one location [Davey et al., 1997; Gillies and Davey, 1986]. During the period 2005 to 2007, three new seismic reflection-refraction surveys were acquired and these data have allowed us to map out and describe what we now refer to as Raukumara Basin (Figure 1). We develop a seismic stratigraphy for the basin, discuss stratigraphic correlations between onshore and offshore, and we analyze the architecture of the basin and consider its genesis and evolution. Our detailed images and analyses of Raukumara Basin are in the context of its well understood tectonic 


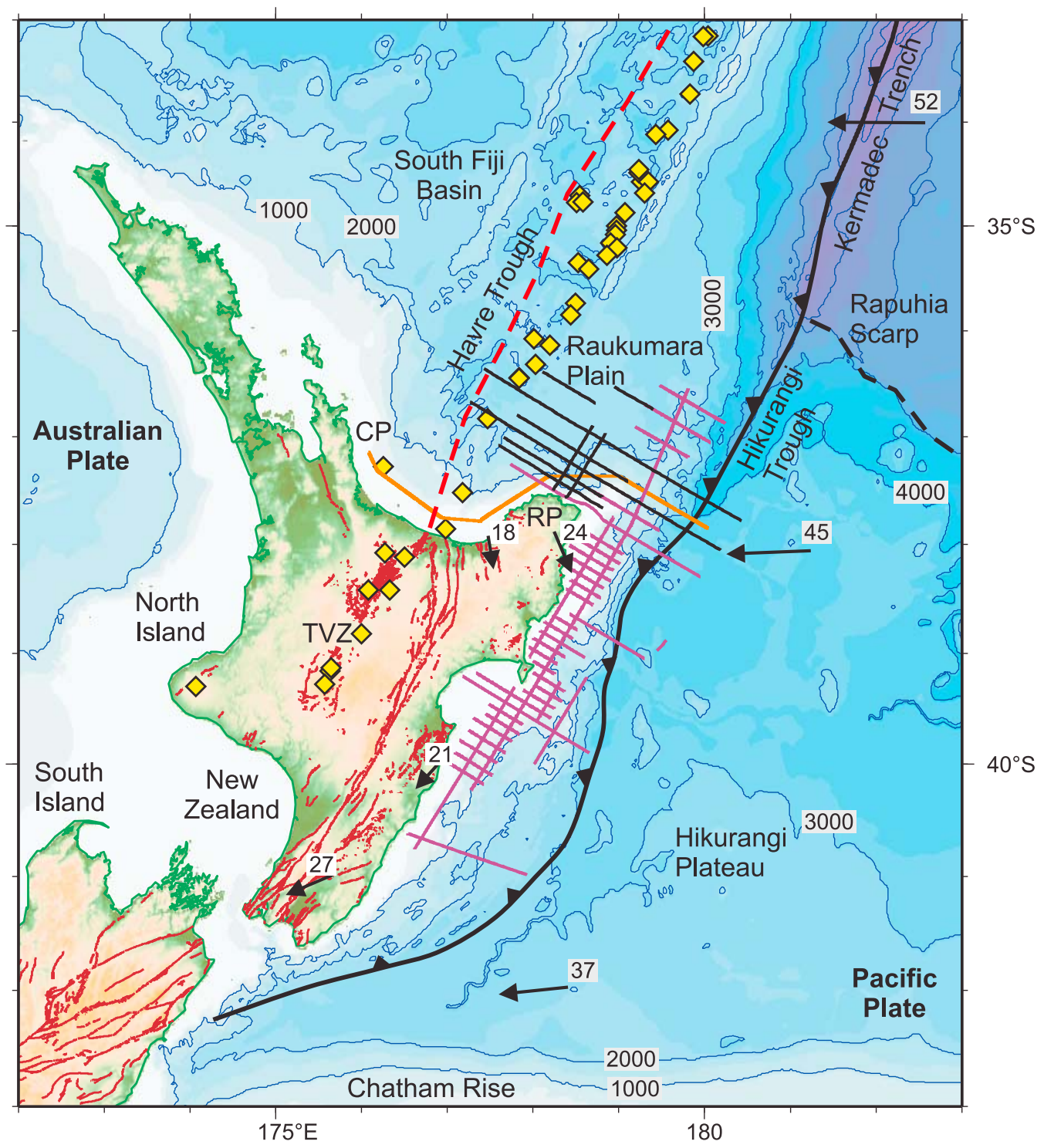

Figure 1. Location of the Raukumara Basin between the Hikurangi Trough subduction front and the Havre Trough back-arc spreading center. Also labeled are the Raukumara Peninsula (RP) and Coromandel Peninsula (CP) and Taupo Volcanic Zone (TVZ). Arrows show long-term motion of the Pacific plate [DeMets et al., 1994] and short-term (GPS) motion of the fore arc [Wallace et al., 2004] relative to a fixed Australian plate. Diamonds show known locations of significant Holocene volcanic centers [de Ronde et al., 2001, 2007; Wright et al., 1996, 2006]. Onshore active faults are shown in dark red (http://data.gns.cri.nz/af/). Offshore seismic lines are colored OGS90 (orange); 05CM (magenta); and RAU07 (black). Bathymetric contours are at $1000 \mathrm{~m}$ interval. The Rapuhia Scarp is the boundary between the Hikurangi Plateau large igneous province and Mesozoic ocean crust [Davy and Collot, 2000; Wood and Davy, 1994].

setting and hence provide insights into active tectonic and basin processes, and may provide a useful analogy for other fore-arc basins.

[3] The Raukumara Basin fore arc and its along-strike transition is of particular relevance to understanding processes and rates of sediment subduction, subduction erosion, and hence the global growth of continental crust. Based upon characterization of the seabed and sedimentary basins at many different subduction margins, it has been suggested that net removal of fore-arc crustal material into the mantle is prevalent globally, and that a significant proportion of incoming sediment may be subducted into the mantle, even at rapidly accreting margins [Clift and Vannucchi, 2004; VonHuene and Scholl, 1991]. On the basis of similar arguments, the region of Raukumara Basin has previously been inferred to be one of net crustal loss 
through sediment subduction and subduction erosion [Clift and Vannucchi, 2004; Collot and Davy, 1998; VonHuene and Scholl, 1991]. On the basis of our new data and analysis, we challenge this view and suggest an alternate hypothesis that fore-arc accretion through lower crustal underplating of subducted material is significant. We are able to conclude this because we have well-mapped and dated stratigraphy in the context of known plate motions, and we have a profound change in crustal structure along strike within the fore arc that provides us with controlled experimental conditions. If we are correct that a significant volume of material is moved to the lower crust of the fore arc, rather than moved into the mantle by subduction, and our results can be generalized to other subduction margins, then the global flux of crustal materials into the mantle at subduction margins is significantly lower than previously thought and new estimates of global crustal growth fluxes are required.

[4] Our new discovery and mapping of the basin is also of substantial regional significance. Raukumara Basin preserves Cretaceous and Paleogene strata, structures, and environmental records in a region that in most other places have been highly deformed during the Cenozoic; and we tentatively identify a fragment of the Mesozoic Gondwana trench slope preserved beneath the western margin of the basin. Raukumara Basin stratigraphy and structure provide constraints on the processes of initiation of Tonga-KermadecHikurangi subduction, and on subsequent fore-arc rotations. The very deep fore-arc basin and associated negative gravity anomaly, by analogy with other subduction zones [Song and Simons, 2003; Wells et al., 2003], may have mechanical significance for the nucleation and propagation of great subduction earthquakes, and is hence also of social and economic interest. Furthermore, it is possible that this newly discovered basin may host significant petroleum resources.

\section{Present Tectonic Setting}

[5] Relative plate motion between the Australian and Pacific plates, according to the NUVEL-1A model [DeMets et al., 1994], is $47 \mathrm{~mm} / \mathrm{yr}$ near the Raukumara Plain, but back-arc extension of $13-16 \mathrm{~mm} / \mathrm{yr}$ in the Taupo Volcanic Zone and Havre Trough [Lamarche et al., 2006; Wallace et al., 2004; Wright et al., 1996] causes the fore arc to move independently of the Australian plate and increases the subduction rate to $\sim 60 \mathrm{~mm} / \mathrm{yr}$ (Figure 1). Numerous volcanoes, caldera, and active hot vent sites are located near to the axis of back-arc extension [de Ronde et al., 2001, 2007; Wright et al., 2006].

[6] The subduction interface and crustal structure onshore, beneath Raukumara Peninsula (Figure 1), has previously been imaged using natural earthquake sources and a dense array of seismomometers [Reyners et al., 1999]. The maximum thickness of continental crust is $30-40 \mathrm{~km}$ beneath western Raukumara Peninsula, as inferred from crustal $\mathrm{V}_{\mathrm{p}}$ estimates of $5.5-6.5 \mathrm{~km} \mathrm{~s}^{-1}$ [Reyners et al., 1999]. Earthquake hypocenters cluster within the upper part of the subducting plate, and in the crust between the east coast of Raukumara Peninsula and the subduction front.
Earthquake focal mechanisms indicate downdip tensional strain within the subducting plate, and NNW-SSE extensional strain within the shallow part of the upper plate [Reyners and McGinty, 1999], consistent with geological and geodetic observations [Arnadóttir et al., 1999]. The uppermost $\sim 10 \mathrm{~km}$ of the mantle of the subducted slab consistently has $\mathrm{V}_{\mathrm{p}}>8.5 \mathrm{~km} \mathrm{~s}^{-1}$, and reduces to more normal mantle velocities of approximately $\mathrm{V}_{\mathrm{p}}=8.2 \mathrm{~km} \mathrm{~s}^{-1}$ beneath [Reyners et al., 1999].

\section{Lithostratigraphy and Structure of Raukumara Peninsula}

\subsection{Jurassic and Cretaceous Gondwana Fore Arc}

[7] The oldest rocks on Raukumara Peninsula are Jurassic and Cretaceous mudstones, sandstones, conglomerate with clasts of silicic igneous rock, and mélange that includes blocks of chert, spilitic basalt and limestone (Figure 2). Indurated, heavily faulted, and isoclinally folded rocks of probable Late Jurassic and Early Cretaceous age contain metamorphic pumpellyite, prehnite, epidote, laumontite (common), datolite, heulandite and stilbite and are locally referred to as the Waioeka terrane of the Torlesse Supergroup (Figure 3) [Coombs et al., 1976; Mazengarb and Speden, 2000; Mortimer, 1994].

\subsection{Cretaceous Syntectonic Sedimentation}

[8] Mudstones, sandstones and conglomerates of the Matawai Group are mostly less indurated than Torlesse Supergroup rocks, but are otherwise similar and overlie Torlesse beds with local angular unconformity [Mazengarb and Harris, 1994; Mazengarb and Speden, 2000]. The entire sequence is interpreted to have been deposited in a tectonically active marine fore-arc shelf basin and trench slope [Crampton, 1996; Mazengarb and Harris, 1994; Mazengarb and Speden, 2000; Speden, 1975; Wellman, 1959]. There is probably no regional unconformity that separates the Torlesse and Matawai groups, and an overlap in age between the two groups is indicated by the occurrence of index fossils with ages $108.4-117.5 \mathrm{Ma}$ in both groups [Crampton et al., 2004] and confirmed by SHRIMP $\mathrm{U} / \mathrm{Pb}$ and fission track ages as young as circa $100 \mathrm{Ma}$ from Torlesse zircons [Cawood et al., 1999; Kamp, 1999].

[9] Ruatoria Group sediments are correlative in age to the Matawai Group, but are only exposed in the eastern part of the region, where they are thought to be allochthonous (see below and Figures 2 and 3). The Matawai and Ruatoria groups (circa 118-84 Ma) show a general trend from shelf or upper slope depositional environments in the west to deeper and more distal deep-water fans (trench settings) in the east [Mazengarb and Harris, 1994; Moore, 1988b]. Eastern domains apparently do not record the older (118$100 \mathrm{Ma})$ deformation events seen farther west, where successive deformation events are associated with a progressive shallowing of inferred depositional environments from deep-water fans to upper slope facies with time [Mazengarb and Harris, 1994]. Silicic tuffs are present within the Matawai Group [Mazengarb and Speden, 2000]. 


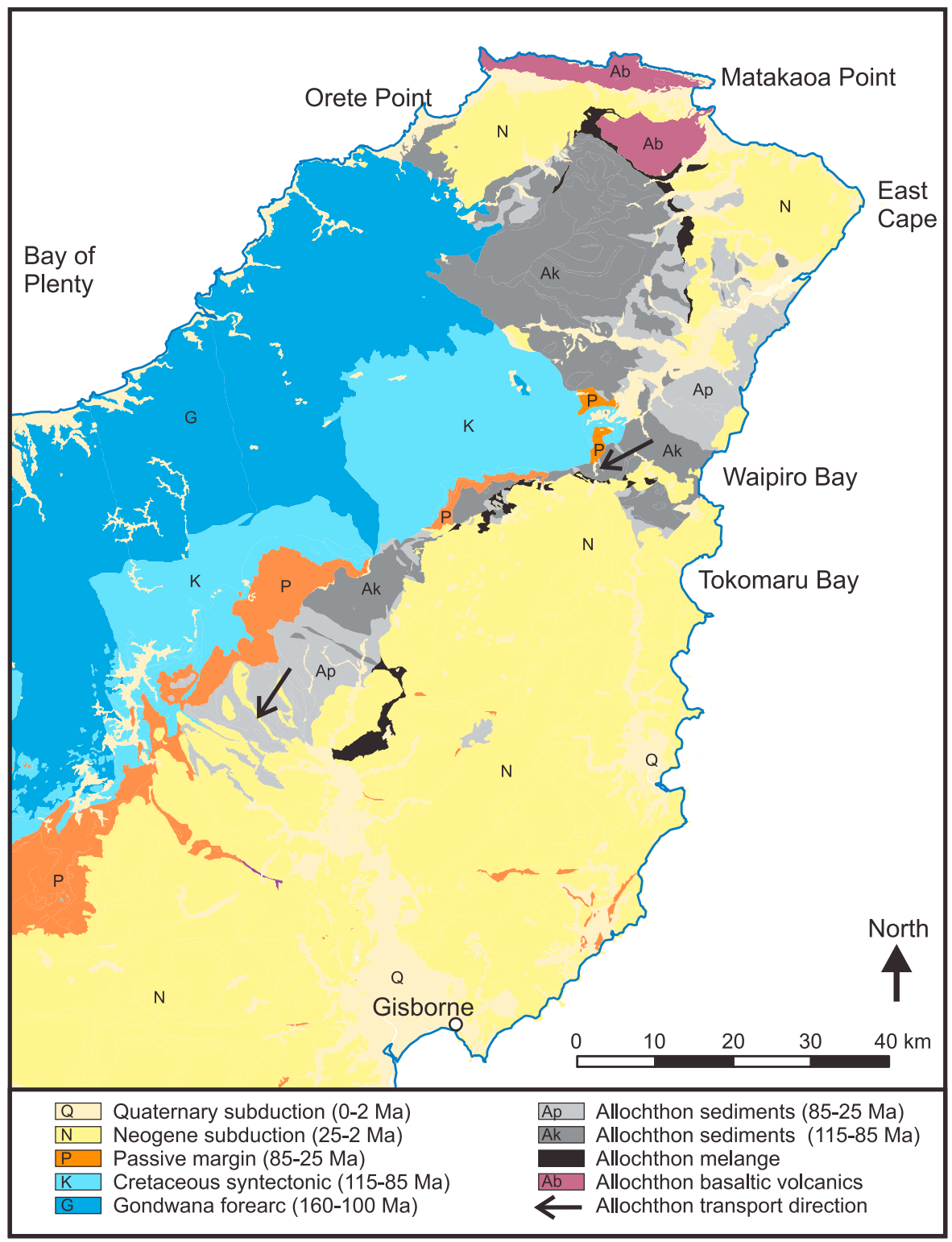

Figure 2. Geology of onshore Raukumara Peninsula [Mazengarb and Speden, 2000] showing autochthonous units: Torlesse Supergoup (Gondwana fore-arc sediments); Matawai Group (Cretaceous syntectonic megasequence); amalgamated Tinui and Mangatu Groups (passive margin megasequence); and amalgamated Tolaga and Mangaheia groups and Quaternary sediments (Neogene megasequence). The East Coast Allochthon is differentiated into Matakaoa volcanics; melange; Ruatoria Group sediments (115-85; correlatives of the Matawai Group); and amalgamated Tinui and Mangatu groups (85-25 Ma). Allochthon transport direction is shown for southern and central exposures, where detailed structural analysis has been completed [Rait et al., 1991; Stoneley, 1968]. See Figure 3.

Stratigraphic relationships above and below the unconformity that defines the top of the Matawai Group demonstrate that Cretaceous folding locally continued until at least 84-86 Ma [Crampton et al., 2004; Mazengarb and Harris, 1994; Mazengarb and Speden, 2000].

\subsection{Late Cretaceous and Paleogene Passive Margin}

[10] Marine mudstones with subordinate siltstones and sandstones were deposited in shelf and slope environments between circa $85 \mathrm{Ma}$ and circa $25 \mathrm{Ma}$ and these strata are generally concordant and only gently deformed, with an inferred Neogene age of deformation, suggesting a passive margin setting for the depositional interval [Field and Uruski, 1997; Mazengarb and Speden, 2000; Moore et al., 1986].

[11] The oldest sediments within this megasequence (basal Tinui Group e.g., Tahora Formation) contain finegrained sandstone facies with a typical thickness of $\sim 100 \mathrm{~m}$, though the thickness may reach $500 \mathrm{~m}$ in western Raukumara 


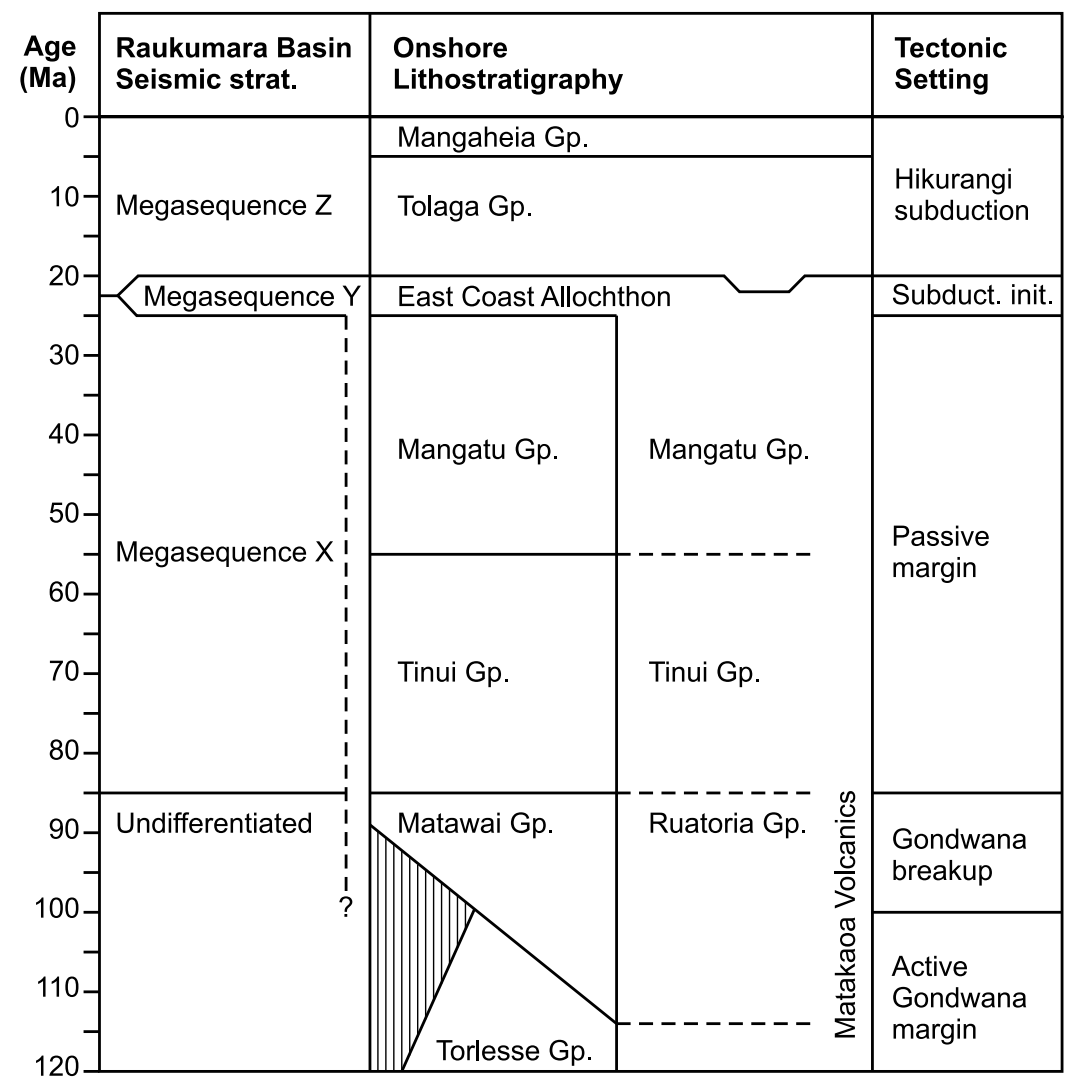

Figure 3. Correlation of seismic stratigraphy with onshore lithostratigraphy.

Peninsula (e.g., coastal and inner shelf facies of Maungataniwha Member) and is transitional with interbedded siltstones farther east (outer shelf or slope facies of Mutuera Member) [Crampton and Moore, 1990; Field and Uruski, 1997; Isaac et al., 1991]. This sandy basal unit is overlain by $300-600 \mathrm{~m}$ of siliceous mudstone (Whangai Formation) that is inferred to thicken and become more calcareous in the east (within the East Coast Allochthon - see below); the mudstone is mostly inferred to have been deposited in deep water $(>200-400 \mathrm{~m})$ and contains rare debris flows [Field and Uruski, 1997; Lillie, 1953; Moore, 1988a]. The uppermost part of the Tinui Group is a thin $(\sim 20 \mathrm{~m})$ black shale (Waipawa Formation) of late Paleocene age that has high (typically 2-6\%) total organic carbon [Hollis et al., 2005; Killops et al., 2000; Moore, 1989].

[12] A further $600 \mathrm{~m}$ thickness of mud-rich sediments (Mangatu Group) were deposited at midbathyal depths $(>400 \mathrm{~m})$ during Eocene and Oligocene time [Field and Uruski, 1997]. Eocene mudstones (Wanstead Formation) are commonly calcareous and glauconitic, and locally contain a relatively high proportion of smectite; glauconitic Eocene sandstones are also locally present. Oligocene sediments (Weber Formation) are calcareous, alternating, glauconitic sandstone and mudstone, and bioturbated calcareous massive mudstone [Field and Uruski, 1997; Mazengarb and Speden, 2000; Moore et al., 1986].

\subsection{East Coast Allochthon}

[13] Rocks older than Miocene in the north and east of Raukumara Peninsula are inferred from structural mapping to be allochthonous [Mazengarb and Speden, 2000; Rait et al., 1991; Stoneley, 1968]. Fault-bounded rock slices of what is referred to as the East Coast Allochthon are imbricated and internally deformed, and it is thought they were emplaced southwestward by tens or even hundreds of kilometers of displacement along low-angle detachment faults [Rait et al., 1991].

[14] Correlative rock types for most of the in-place (autochthonous) sedimentary units (described above) can be found within the allochthon, along with some additional rock types (Figures 2 and 3). Of particular note are the Matakaoa Volcanics, which are primarily subalkaline and tholeitic basaltic eruptive facies that are exposed near the northern tip of Raukumara Peninsula (Figure 2). Attempts to $\mathrm{K} / \mathrm{Ar}$ date Matakaoa Volcanics have so far produced ages that are younger than the ages of intercalated sediment, which is inferred from foraminifera and radiolaria to have late Early Cretaceous (Albian; 112-100 Ma), Late Cretaceous and Paleocene ages; and so it is inferred that radiometric ages were partially reset during deformation [Aita and Sporli, 1992; Brothers and Delaloye, 1982; Sporli and Aita, 1994; Strong, 1976; Strong, 1980]. It has been postulated, based upon geochemical comparisons, that the Matakaoa Vol- 


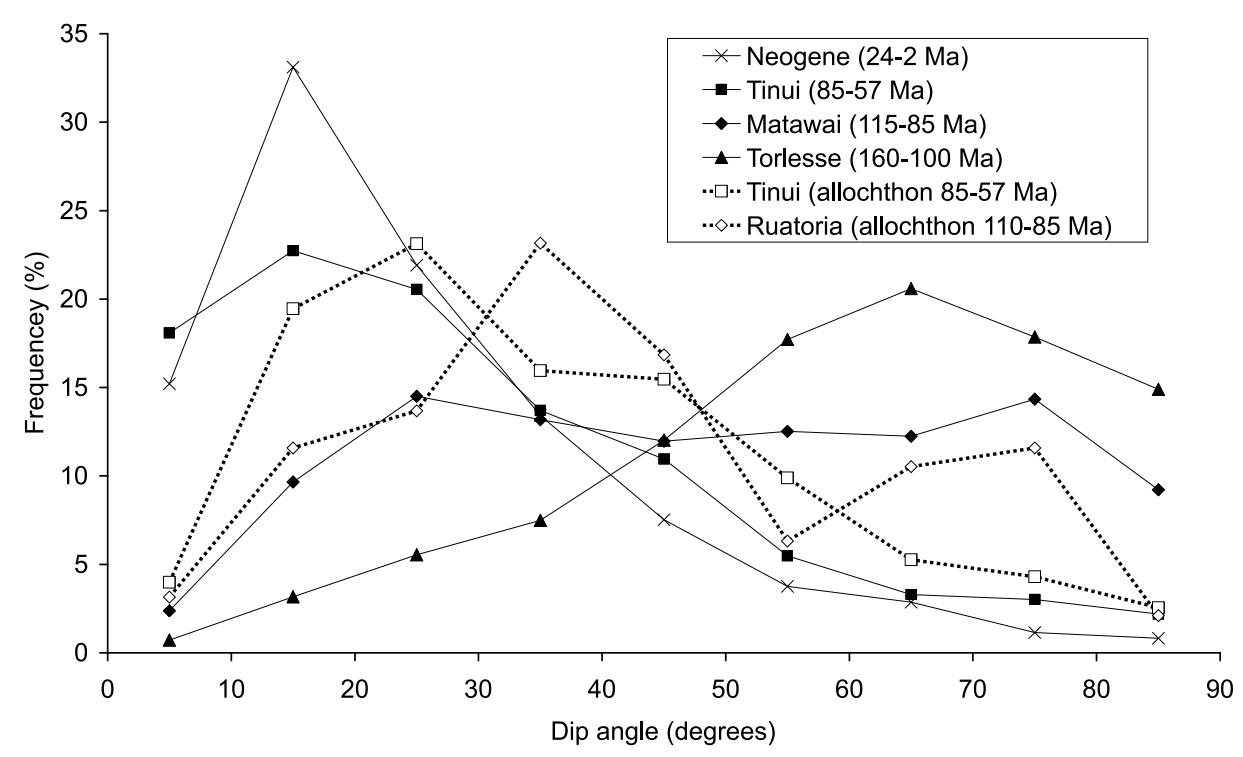

Figure 4. Histogram of sedimentary dip angles from onshore Raukumara Peninsula autochthonous (in place) Neogene $(\mathrm{N}=1223)$, Tinui Group $(\mathrm{N}=365)$, Matawai Group $(\mathrm{N}=1813)$, and Torlesse Supergroup $(\mathrm{N}=1389)$ sedimentary rocks; and allochthonous Tinui Group $(\mathrm{N}=627)$ and Ruatoria Group $(\mathrm{N}=94)$ sediments [Mazengarb and Speden, 2000]. Proportion of localities with overturned or transposed beds are $2 \%, 11 \%$, and $10 \%$ for autochthonous Tinui, Matawai, and Torlesse groups, respectively; and 10\% and 36\% for allochthonous Tinui and Ruatoria groups, respectively. See Figures 2 and 3.

canics are fragments of the Hikurangi Plateau that have been accreted to the fore arc by subduction processes. The Hikurangi Plateau probably formed at circa $122 \mathrm{Ma}$, but has numerous younger seamounts erupted on to it [Mortimer and Parkinson, 1996; Wood and Davy, 1994].

[15] The timing and environment of allochthon emplacement are constrained by stratigraphic observations. The youngest preemplacement sediments (Weber Formation) are biostratigraphically dated as 25-22 Ma (Waitakian stage); the oldest sediments deposited in "piggyback" basins above the allochthon (e.g., Whakai Formation) are biostratigraphically dated as $22-16 \mathrm{Ma}$ (Otaian to Altonian stages); and sediments dated at 25-19 Ma (Waitakian to Otaian stages) are tuffaceous in places and commonly contain coarse blocks of older sediment, rounded pebbles of basalt and gabbro, and hence some are inferred to be synemplacement deposits [Field and Uruski, 1997; Mazengarb and Speden, 2000].

\subsection{Neogene Subduction Margin}

[16] There was a profound change in depositional environment during and after emplacement of the East Coast Allochthon. Oligocene sediments that predate allochthon emplacement are predominantly clay-rich pelagic mudstone and limestone (above), whereas the Miocene (Tolaga Group) and Pliocene (Mangaheia Group) sedimentary sequence is much thicker and composed of marine sandstone, siltstone, and mudstone with minor conglomerate, limestone and reworked tuffaceous deposits [Field and Uruski, 1997; Mazengarb and Speden, 2000]. The Neogene sequence represents a range of marine shelf and trench slope depositional environments and is characterized by abundant terrigenous clastic and minor volcaniclastic sediment input, consistent with the onset of significant Australia-Pacific plate displacement through central New Zealand and the local establishment of a subduction plate boundary with a volcanic arc [Cande and Stock, 2004; Herzer, 1995; Rait et al., 1991].

\subsection{Onshore Structure}

[17] Neogene sediments are gently or moderately dipping (Figure 4) and folded about NNE-SSW axes that are subparallel to the modern plate boundary [Mazengarb and Speden, 2000]. Neogene shortening of the fore arc represents only a very small proportion of the total plate shortening, which is mostly accommodated near to the subduction interface [Nicol et al., 2007; Nicol and Wallace, 2007]. Uplift of the Raukumara ranges is inferred to have been primarily driven by crustal underplating near the subduction interface or changes in the type of lithosphere being subducted, rather than through widespread faulting and crustal thickening associated with large-scale pure shear of the overriding plate [Eberhart-Phillips and Reyners, 1999; Reyners et al., 1999; Uruski et al., 2006; Walcott, 1987; Wilson et al., 2007].

[18] The Matawai Group (115-85 Ma) was deposited during a phase of Cretaceous deformation and beds were progressively tilted as further deposition occurred [Mazengarb and Harris, 1994]. This has resulted in a broad range of observed dips (Figure 4) that depend upon stratigraphic 


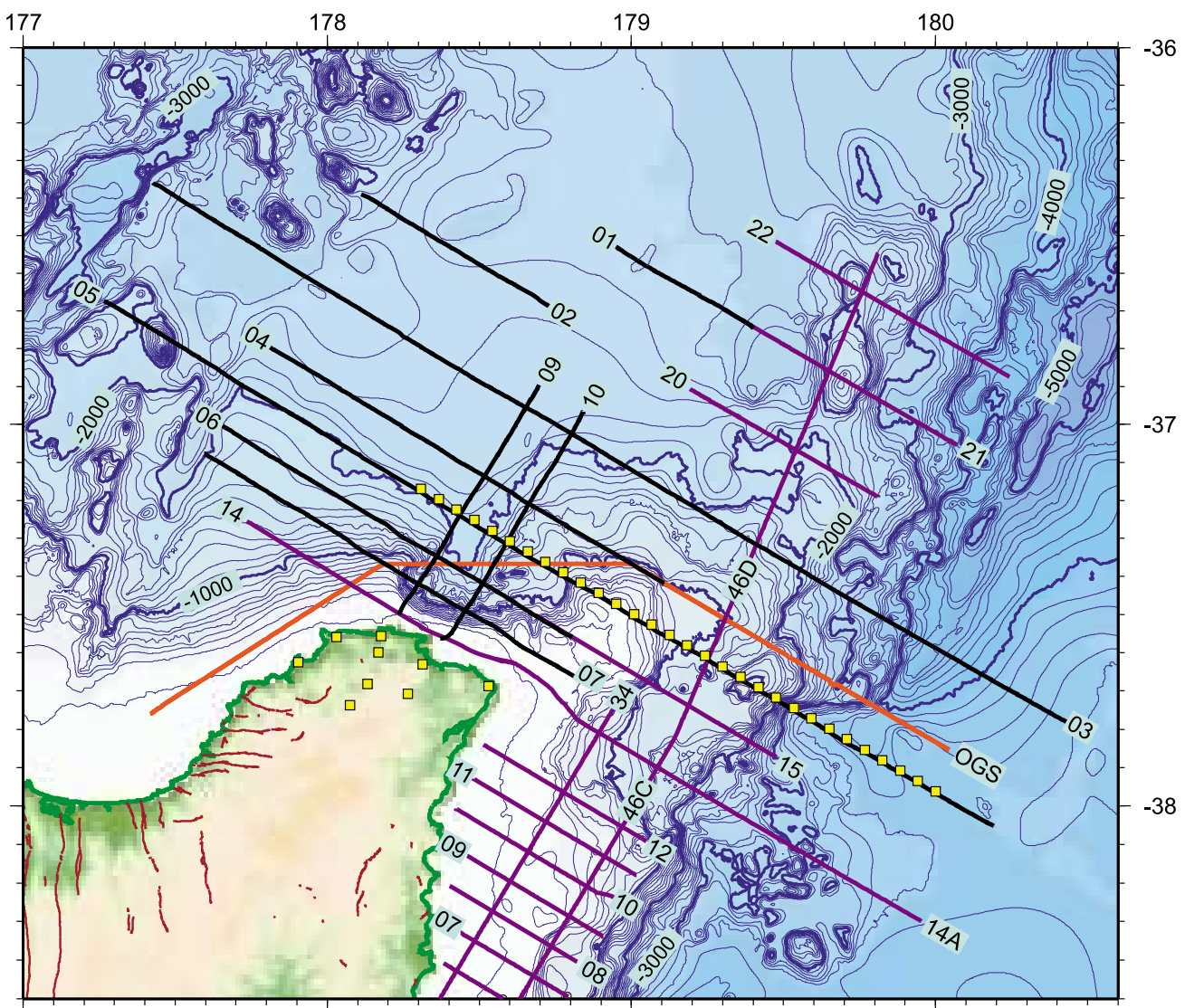

Figure 5. Location of RAU07 (black), 05CM (purple), and OGS90 (orange) surveys; labels indicate line numbers. Yellow squares show locations of onshore and ocean bottom recording stations. Bathymetric contours are at $100 \mathrm{~m}$ increments [CANZ, 2008].

age and location. In contrast, Torlesse Supergroup sediments $(160-100 \mathrm{Ma})$ are predominantly steeply dipping (Figure 4). This may partially be the result of deformation that predates deposition of the Matawai Group, but it could also be that the distribution of Torlesse bedding orientations represents an end point for the deformation style that occurred during Matawai Group deposition, i.e., the earlier deformation was completely overprinted.

[19] Emplacement of the East Coast Allochthon in latest Oligocene and earliest Miocene times (25-19 Ma) was associated with large displacements of weakly lithified sediments along low-angle faults and internal shortening of nappes along thrust faults and folds [Mazengarb and Speden, 2000; Rait et al., 1991; Stoneley, 1968]. Despite large inferred displacements, most beds within the allochthon have gentle or moderate dips (typically $15-45^{\circ}$; Figure 4 ). The deformation event caused an increase in average dip of the previously undeformed Tinui Group, and a reduction in average dip of Ruatoria Group beds (correlative to the Matawai Group), which were also deformed during Cretaceous time. The event also produced overturned nappes and isoclinal folds: $10 \%$ of Tinui Group and $36 \%$ of Ruatoria Group localities have overturned bedding.

[20] The allochthon is inferred to have been emplaced toward the southwest in the southern and central areas, where its structure has been studied in detail (Figure 2) [Kenny, 1984; Rait et al., 1991; Stoneley, 1968]. Melange was formed during emplacement of the East Coast Allochthon and appears best developed near the top of the allochthon (Figure 2). Local structural mapping demonstrates that allochthonous material, particularly melange and Wanstead Formation mudstone, is weak and associated with Neogene diapiric deformation and Quaternary slope failure [Mazengarb and Speden, 2000].

\section{Seismic Reflection Data}

[21] We have used results from three MCS surveys (Figure 5), supplemented by older data, to map and understand Raukumara Basin. The RAU07 survey was acquired in 2007 using a 86.51 (5280 cu in) source and $7.3 \mathrm{~km}$ streamer, with $37.5 \mathrm{~m}$ shotpoint spacing and $13.3 \mathrm{~s}$ record length for all lines except RAU07-05, which had $50 \mathrm{~m}$ shotpoint spacing and $15.3 \mathrm{~s}$ record length. Details of data processing are given elsewhere (Fugro Seismic Imaging, Raukumara Basin 2D Seismic Survey-RAU07, New Zealand unpublished open file petroleum report 3743, 2007). The 05CM data set was acquired in 2005 using a 67.81 (4140 cu in) source and streamer that varied between $12 \mathrm{~km}$ and $4 \mathrm{~km}$ (due to shark attacks), with $37.5 \mathrm{~m}$ 
shotpoint spacing and $8 \mathrm{~s}$ or $12 \mathrm{~s}$ record length (G. Maslen, Fast track seismic processing of selected data from the 05CM Survey offshore east coast New Zealand, unpublished open file petroleum report 3182, 2005; Multiwave, 05CM 2D seismic survey, offshore east coast-North Island, New Zealand, unpublished open file petroleum report, $3136,2005)$. The OGS90 line was acquired in 1990 using a 45.21 (2756 cu in) source and $3 \mathrm{~km}$ streamer, with $50 \mathrm{~m}$ shotpoint spacing and $16 \mathrm{~s}$ record length [Davey et al., 1997], and was reprocessed with the RAU07 data (Fugro Seismic Imaging, unpublished report, 2007).

\section{Seismic Reflection Stratigraphy}

\subsection{Megasequence $Z$}

[22] The upper surface of megasequence $Z$ is the seabed; and the lower surface is defined in central parts of the basin as being the lowermost reflector within a unit of continuous or semicontinuous reflectors that becomes thicker toward the northwest; elsewhere the base is correlated geometrically to where it is defined in central or eastern parts of the basin (Figure 6). Reflectors near to the base of the unit are mostly continuous and northwest dipping, have high amplitude, and have a geometry that fans and thickens toward the center of the basin. Onlap and downlap relationships within the unit are interpreted as slope and basin floor fans. Toward the top of the megasequence there are several units characterized by discontinuous reflectors or that have no coherent internal acoustic structure, and in some places have a reverse polarity reflection at the base; we interpret these as internally chaotic mass transport deposits. The uppermost units of this type in central and southern parts of the basin are interpreted to be associated with the Matakaoa Submarine Instability Complex, which was active from circa $600 \mathrm{ka}$ to $40 \mathrm{ka}$ and has left notable erosional scarps and stranded blocks of debris at the seabed [Lamarche et al., 2008].

[23] The eastern limb of the basin underlies East Cape Ridge, which is adjacent to the Hikurangi trench slope and active plate boundary (Figure 7). Strata of the eastern basin limb dip WNW toward the center of the basin, as does the submarine topographic slope, where several modern and ancient submarine slope failures and associated deposits are identified. A complex and faulted stratigraphy of angular unconformities is identified within megasequence $\mathrm{Z}$ on East Cape Ridge. The trench slope is highly faulted and poorly imaged, and we agree with previous workers that normal faulting is widespread on the upper part of the slope and across some parts of East Cape Ridge [Collot and Davy, 1998; Collot et al., 1996]. On the basis of improved seismic reflection coverage and a detailed bathymetric grid [CANZ, 2008], we have not been able to confirm the presence of major linear strike-slip faults on the upper part of East Cape Ridge, as have been previously postulated [Collot and Davy, 1998; Davey et al., 1997], though significant faults (with curved geometry) are imaged near the crest of the ridge and we have not made a detailed study of the trench slope.

[24] Reflectors in the upper half of megasequence $Z$ have higher amplitude and frequency content at the western basin margin than is typical for the central basin, and are semicontinuous and variable in character. Sequences thin and downlap toward the basin center, and we interpret these sequences as being associated with arc volcaniclastic input. Megasequence $\mathrm{Z}$ becomes indistinct at some places along the northwestern edge of the basin, where there is topographic and geothermal-geochemical evidence for active volcanism [de Ronde et al., 2001, 2007; Wright et al., 2006]. We interpret the loss of coherent reflectors within megasequence $\mathrm{Z}$ at the northwestern edge of the basin to be locally associated with volcanic and hydrothermally altered rocks adjacent to active volcanic centers.

[25] At the southern margin of the basin, megasequence $\mathrm{Z}$ has been uplifted and strata dip northward toward the basin center (Figure 8). Repeated slope failures associated with this uplift are responsible for the Matakaoa Erosional Complex, which is the source of debris avalanche deposits that are mapped in central parts of the basin [Lamarche et al., 2008].

[26] The thickness of megasequence $\mathrm{Z}$ increases toward the north from $\sim 1 \mathrm{~s}$ two-way traveltime (twt) near the shelf edge to $>2.5 \mathrm{~s}$ twt $(2-3 \mathrm{~km}$ thickness) in northern parts of the basin (Figure 9). The southern margin has reduced thickness due to both a smaller accommodation space and erosion because of late Neogene uplift. The base of megasequence $Z$ rises gently to the south and to the east, and is offset by normal faults at its western margin in the Havre Trough (Figures 7 and 10). The Tokata Anticline [Lamarche et al., 2008] deforms megasequence $\mathrm{Z}$ and is mapped along the base of the western edge of East Cape Ridge (Figure 10), where it is locally faulted (Figure 7). An array of minor tensional faults are mapped in the northeastern part of the basin, and several significant normal faults are mapped near to the crest of East Cape Ridge (Figure 10).

\subsection{Megasequence $Y$}

[27] Megasequence $\mathrm{Y}$ is only present between East Cape Ridge and the center of the basin. It is defined as a unit of chaotic and variably dipping discontinuous reflections (Figure 6) with a typical thickness of $\sim 1 \mathrm{~s}$ twt, and pinching out toward the center of the basin (Figures 6, 7, and 9). Coherent blocks of dipping reflectors within the unit are interpreted as large blocks of sedimentary material. Numerous small faults are interpreted that bound these blocks and in other places the unit appears acoustically chaotic or transparent, which we interpret to be highly deformed sedimentary or volcanic material. The top of the unit has numerous small "piggyback" basins with continuous high-amplitude reflections that typically dip toward the center of each depression. We interpret megasequence $\mathrm{Y}$ as a single very large submarine slope failure with depressions on its top being filled with synemplacement reworked sediment.

[28] Megasequence $\mathrm{Y}$ dips northwestward beneath the flank of East Cape Ridge (Figure 10) and is subparallel to the seabed, dropping $\sim 2 \mathrm{~km}$ beneath the ridge and central basin. Numerous small faults within megasequence $Z$, mostly normal faults, appear to root into megasequence $Y$. We also speculate that the Tokata Anticline, visible at the 


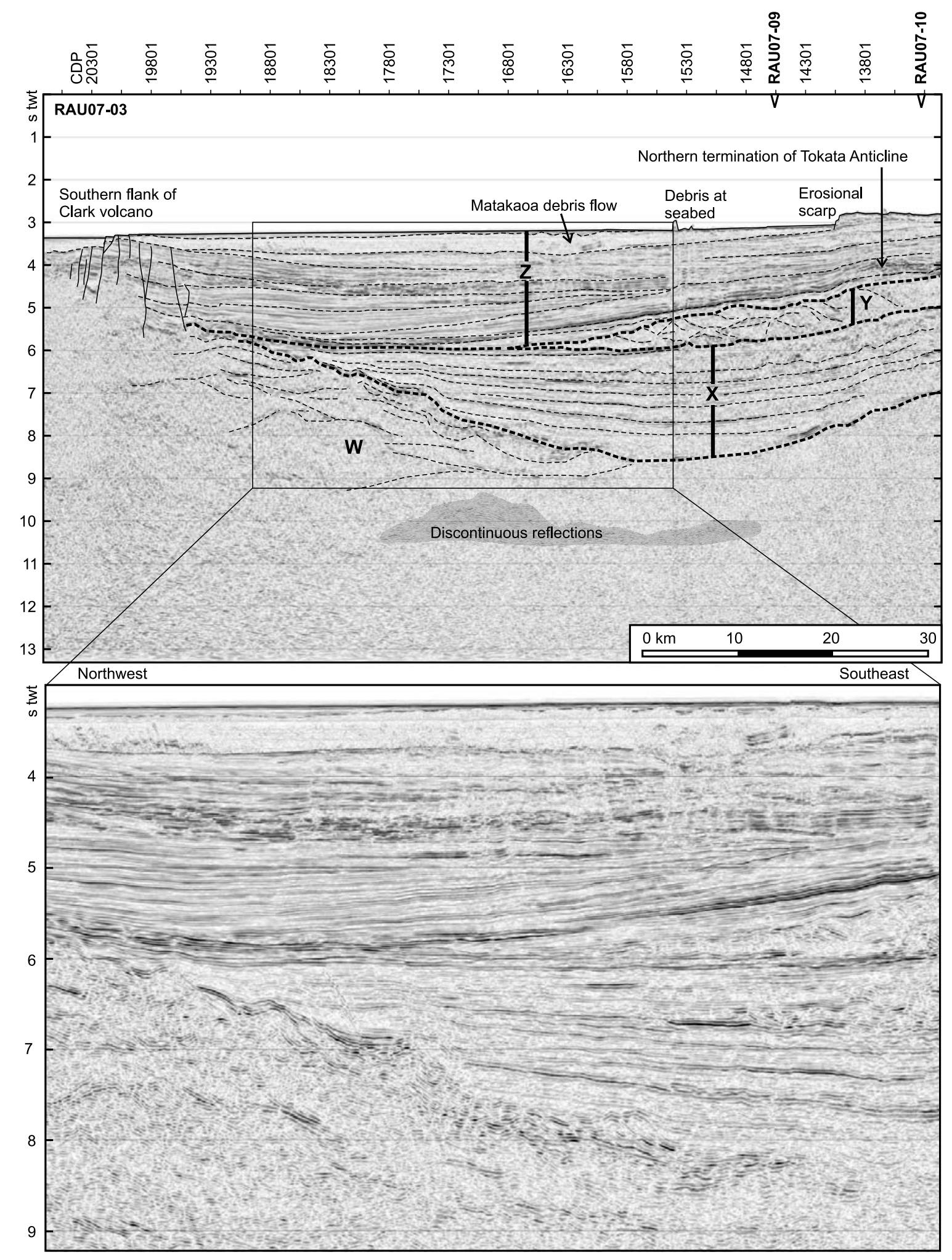

Figure 6. Seismic stratigraphy (megasequences X, Y, Z labeled) illustrated on seismic reflection section RAU07-03. The area labeled $\mathrm{W}$ is the wedge-shaped unit of coherent but semicontinuous reflections inferred to be the Cretaceous Gondwana fore-arc trench slope (see main text). 


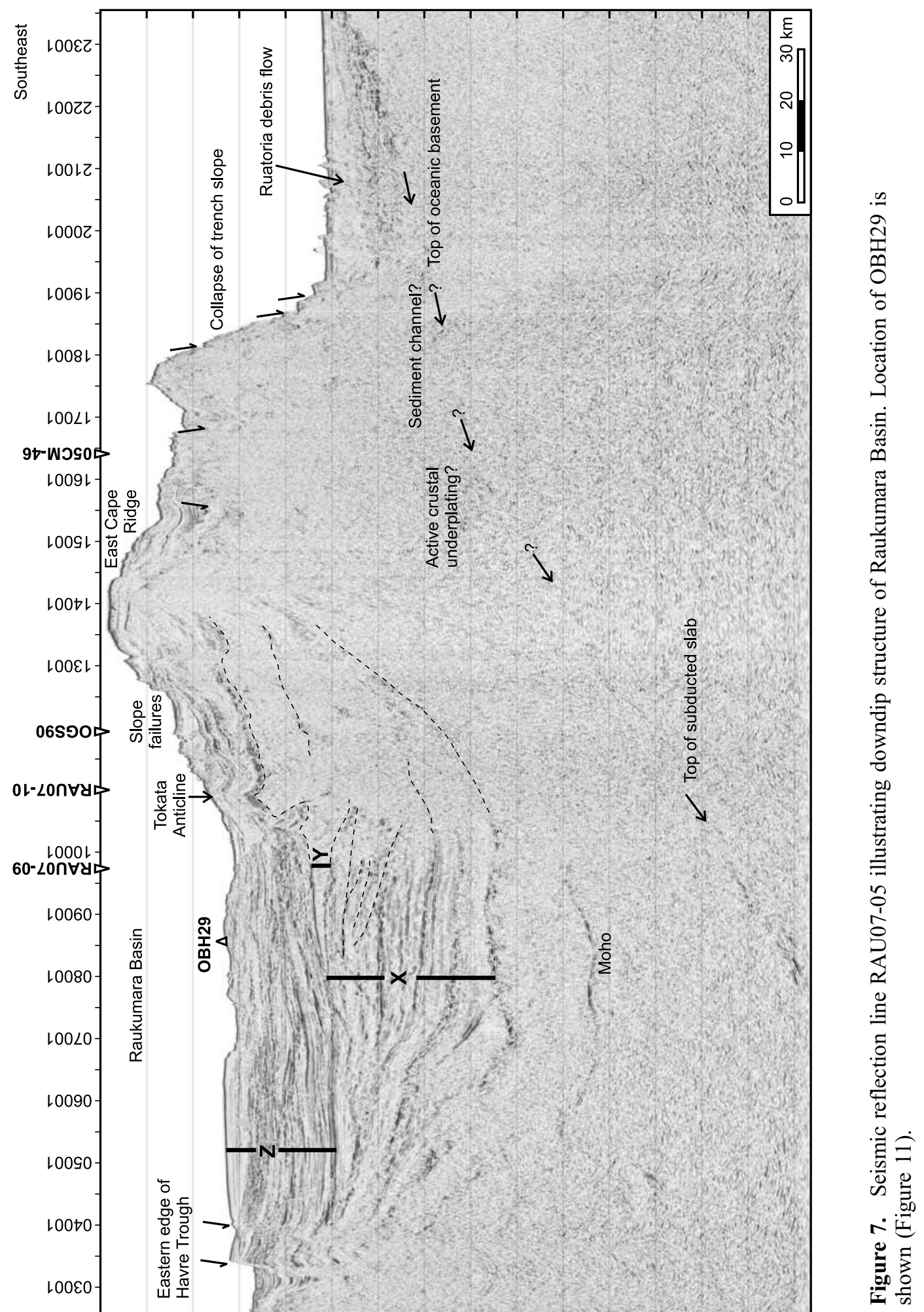

10 of 23 


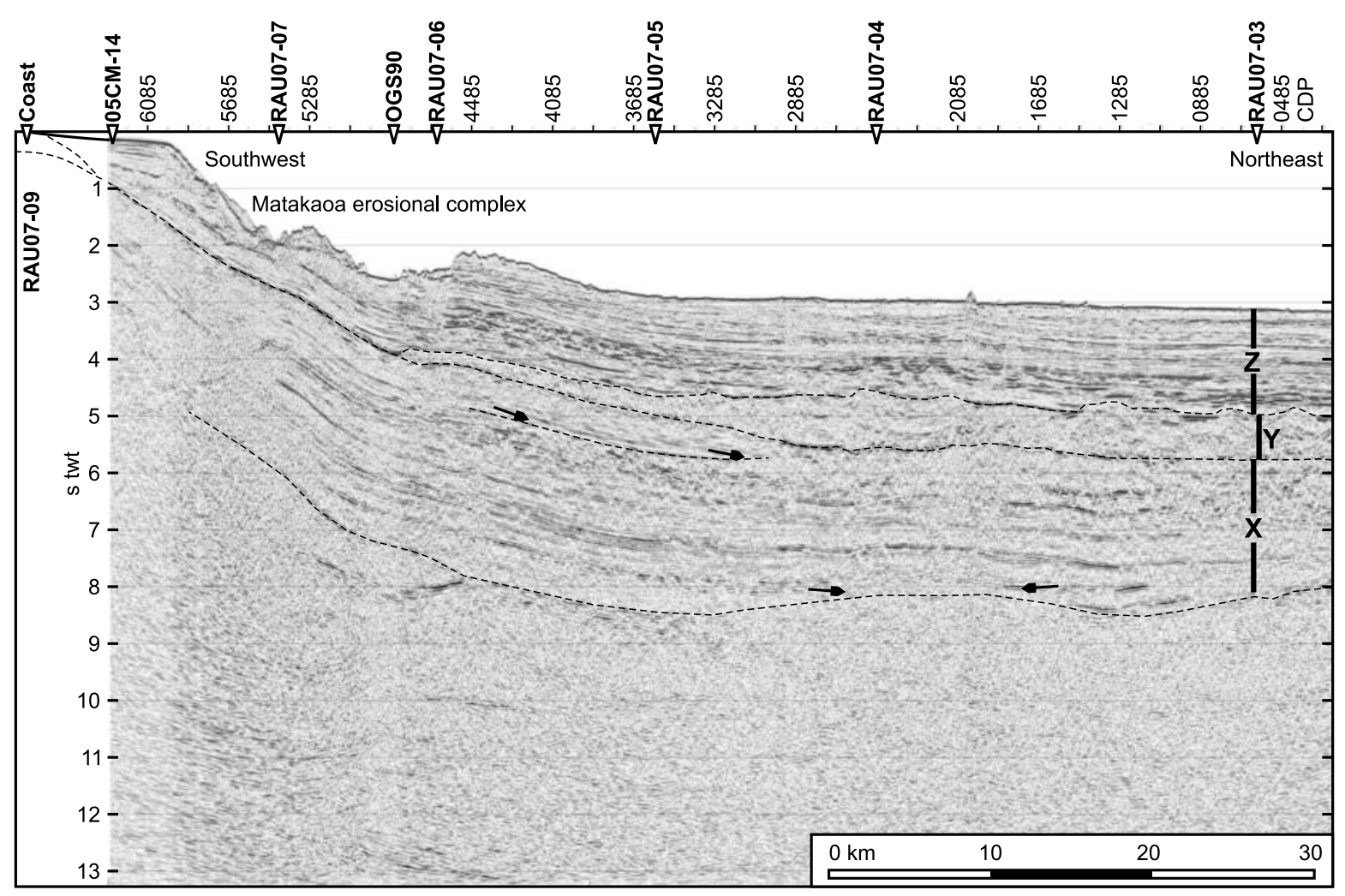

Figure 8. Seismic reflection line RAU07-09 showing along-strike structure of Raukumara Basin. Small arrows show downlap relationships discussed in text. Matakaoa Volcanics are exposed on the coast and are considered allochthonous, but it is not known if the allochthon offshore is precisely the same stratigraphic age. An alternate correlation with the base of the Matakaoa Volcanics is the marked sequence boundary with northward downlapping relationships above it.

base of the slope (Figures 6, 7, and 10), and the faulted anticline on line RAU07-05 may be part of a large Quaternary slope failure detaching through megasequence $\mathrm{Y}$ and driven by the topography of East Cape Ridge.

[29] Megasequence $\mathrm{Y}$ also dips northward away from the coast, but thins and is not present offshore near to the coast. However, there is a significant downlapping sequence boundary within the upper part of megasequence $\mathrm{X}$ directly beneath (Figure 8). This is discussed further when offshoreonshore correlations are considered.

\subsection{Megasequence $X$}

[30] The top of megasequence $\mathrm{X}$ is defined as the first continuous or semicontinuous reflector below megasequence $\mathrm{Y}$, or by the equivalent stratigraphic level at which megasequence $\mathrm{Y}$ was emplaced (Figure 6). This corresponds in the center of the basin to the deepest in a packet of high-amplitude reflections at the base of megasequence $Z$; a packet that we interpret as being the sedimentary unit that was deposited at the time megasequence $\mathrm{Y}$ was emplaced.

[31] Megasequence $\mathrm{X}$ is characterized in central and western parts of the basin by continuous or semicontinuous reflectors that dip and fan toward the east, causing the unit to increase in thickness from $<1 \mathrm{~s}$ twt near the margin of the
Harve Trough to $3-4 \mathrm{~s}$ twt $(\sim 5-8 \mathrm{~km})$ in the center of the basin (Figure 9). There are at least five sequences within megasequence $\mathrm{X}$ that can be distinguished on the basis of reflection amplitude, onlap, and sequence geometry. The base of megasequence $\mathrm{X}$ is defined by the deepest continuous or semicontinuous reflector with the unit.

[32] Megasequence $\mathrm{X}$ is less well imaged beneath East Cape Ridge, on the east flank of the basin, where west dipping high-amplitude discontinuous reflectors are probably continuous with megasequence $\mathrm{X}$ in the central basin and suggest the unit has a similar or slightly lower thickness (Figure 9). The lower part of megasequence $\mathrm{X}$ has been deformed into northeast trending open folds along the western basin margin, suggesting minor convergent deformation before emplacement of megasequence Y.

\subsection{Acoustic Basement}

[33] Acoustic basement is defined as everything below megasequences X-Z (Figure 6). In eastern parts of the basin there are continuous high-amplitude reflectors and packets of coherent reflectors that we interpret as faults and tilted or fault-bounded sediment packages. In the central basin, most units show several high-amplitude semicontinuous reflections at $8-9 \mathrm{~s}$ twt that we infer to be a significant acoustic impedance contrast at the base of the sedimentary section 

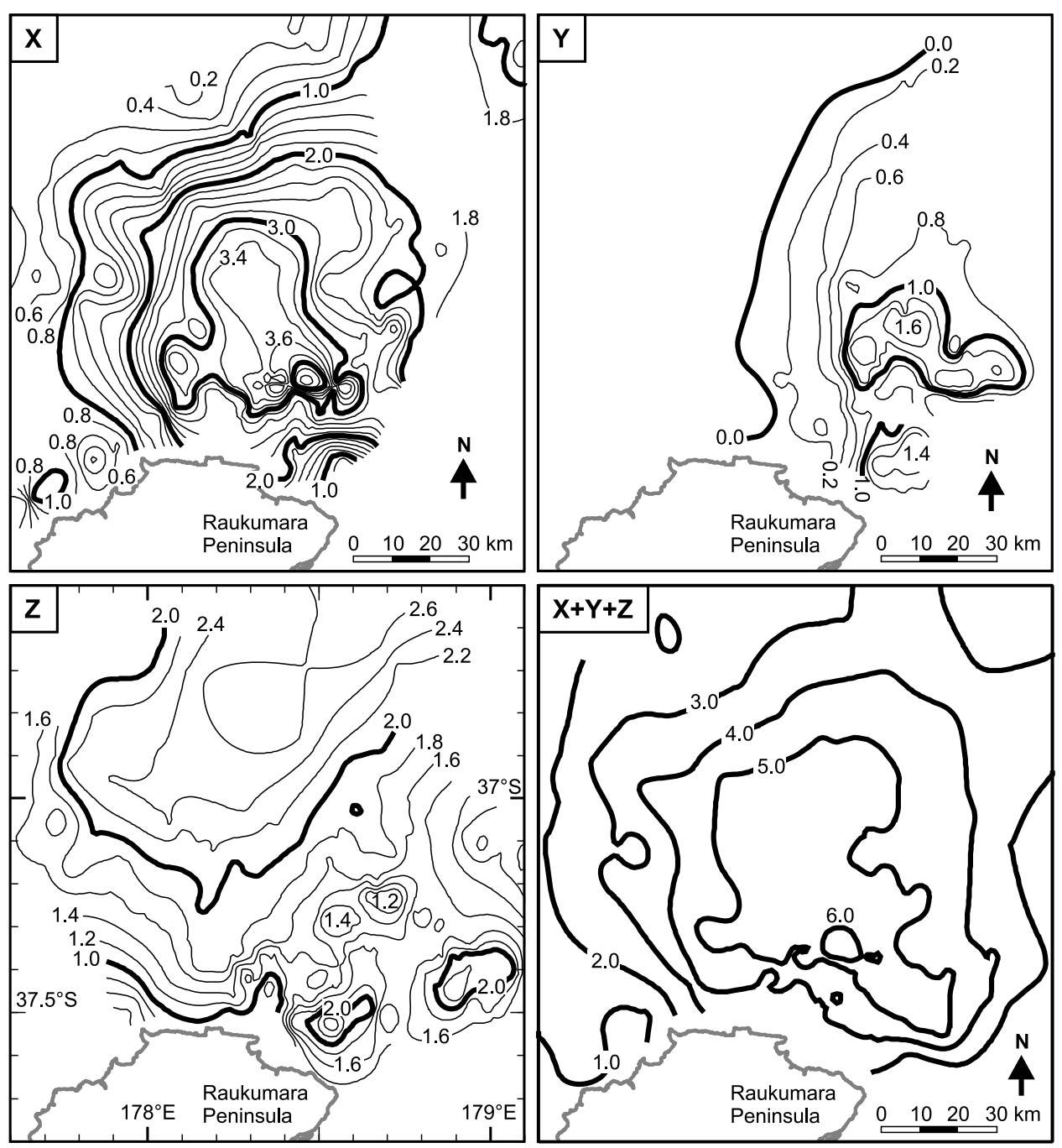

Figure 9. Isopach maps of megasequences $X, Y, Z$ and total sediment thickness $(X+Y+Z)$ in $s$ twt.

(acoustic basement). We identify individual high-amplitude semicontinuous reflections or packets of discontinuous reflections at 10-11 s twt beneath the center of the basin (e.g., Figure 6), that we associate with the Moho; and we show this with refraction data (below). West dipping reflections between 13 and $15 \mathrm{~s}$ twt are identified beneath the central basin on line RAU07-05 (Figure 7), which appear geometrically continuous and aligned with zones of enhanced reflectivity (coherent reflections) beneath East Cape Ridge, that are in turn aligned with the top of the subducted slab where it is imaged at the Hikurangi Trough. Hence, we interpret the reflections at $13-15 \mathrm{~s}$ twt as the top of the subducted slab.

\section{Active Source Seismic Refraction Constraints on Crustal Structure}

[34] In a survey by R/V Sonne in 2007 (MANGO; cruise SO192) shots from a 641 (3905 cu in) air gun source were recorded using ocean bottom seismometers (OBS) and ocean bottom hydrophones $(\mathrm{OBH})$. The shots were fired along a line coincident with RAU07-05, but ocean bottom instrumentation was restricted to central and eastern parts of the line (Figure 5). We present here a preliminary interpretation from the most western instrument, OBH29 (Figures 5 and 11).

[35] A velocity forward model was constructed for OBH29 (Figure 11) on the basis that significant boundaries (reflections) and units of distinct seismic reflection character are identified from MCS data (above), and units with a similar geometry have previously been suggested from a combined interpretation of gravity data and line OGS90 [Davey et al., 1997]. Our results show that our hypotheses for the geometry of the base of the basin and crust inferred from normal incidence reflections on line RAU07-05, combined with fairly typical velocities for sediment, lower crust, and mantle are consistent with observed refracted arrivals. We identify lower crust and mantle refracted arrivals; and obtain crustal velocities of $6.5-7.5 \mathrm{~km} / \mathrm{s}$ and an uppermost mantle velocity of $8.0-8.2 \mathrm{~km} / \mathrm{s}$. The model Moho depth is $17 \mathrm{~km}$ beneath sea level and the subducted slab is located at $30-40 \mathrm{~km}$ (Figure 11). 


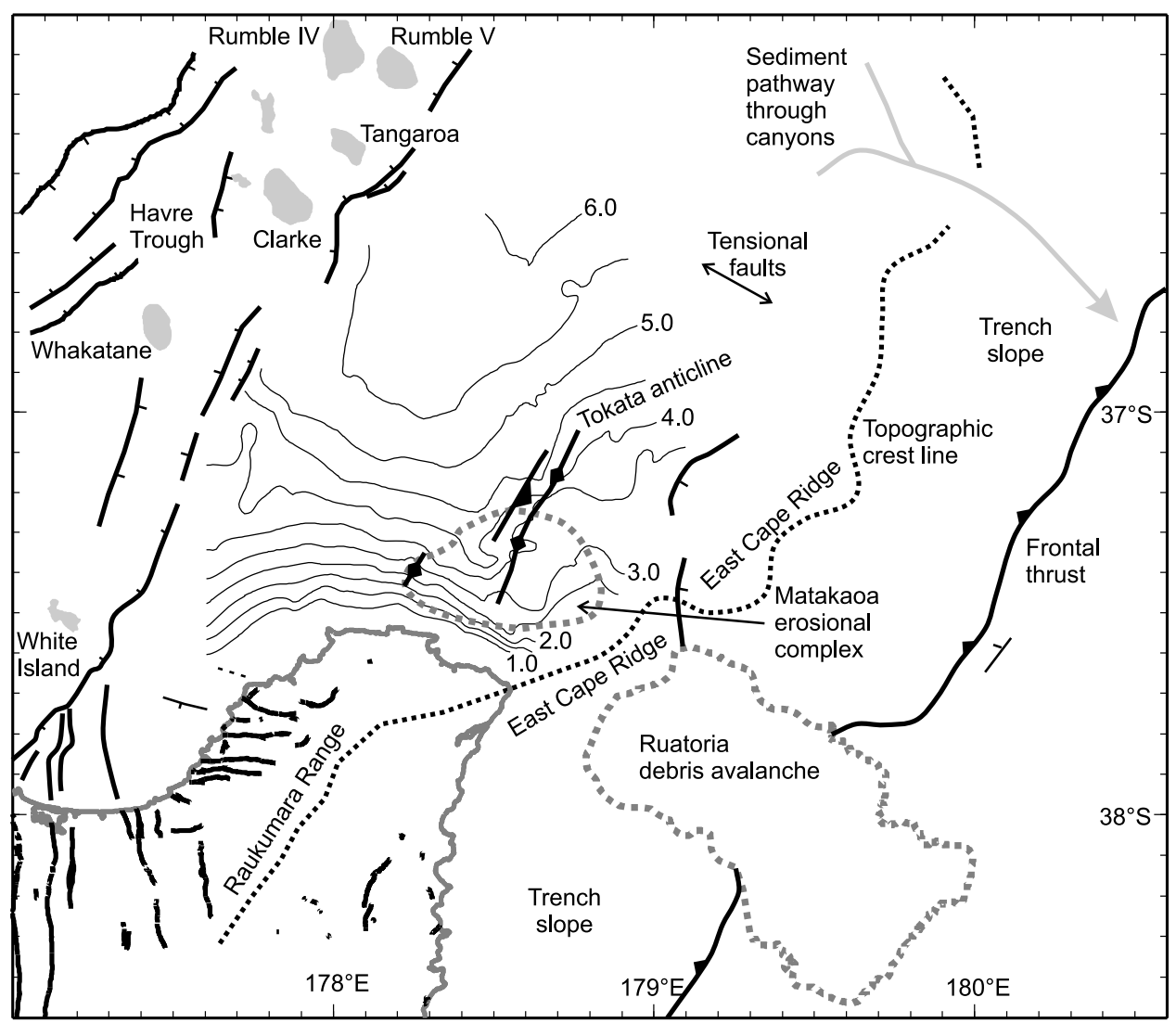

Figure 10. Map of basin structure showing: contours in s twt on the base of megasequence X; thrust faults (teeth show dip direction); major normal faults (ticks show dip direction); anticlines; and locations of Quaternary volcanoes (gray fill).

[36] In addition, shots from survey RAU07 were recorded at 7 onshore locations (Figure 5) and we present a preliminary interpretation in this paper of data from two inland stations along the projection of line RAU07-09 (Figure 12). We construct a velocity forward model for these data on the basis that: 1 , the velocity of the crust beneath the stations is known from earthquake 3-D $\mathrm{V}_{\mathrm{p}}$ tomography [Reyners et al., 1999]; and 2, our models should be consistent at the intersection between lines RAU07-09 and RAU07-05 (Figure 11). Using these assumptions it is possible to successfully model the refracted onshore arrivals from shots of line RAU07-09 (Figure 12).

[37] The results imply changes in crustal structure northeastward along the line: water and sediment thickness increases by $\sim 10 \mathrm{~km}$; crustal (basement rock) thickness decreases by $\sim 20 \mathrm{~km}$; and there is an incoming mantle wedge beneath line RAU07-09 that reaches a thickness $\sim 10 \mathrm{~km}$ above the subducted slab at the intersection with line RAU07-05.

\section{Offshore-Onshore Lithostratigraphic Correlation}

[38] Megasequence $\mathrm{Y}$ is interpreted as a large allochthonous sheet within the basin and is hence a key unit when considering offshore-onshore correlations. This is because a large allochthonous and internally disrupted sheet of similar thickness and scale, the East Coast Allochthon, has been described and studied in detail onshore and is an obvious correlative. In addition, we can interpolate directly between the mapped position of megasequence $\mathrm{Y}$ and the mapped onshore allochthon using lines RAU07-09 and RAU07-10. From this we infer that megasequence $\mathrm{Y}$ was emplaced at about the same time as the East Coast Allochthon in latest Oligocene or/and earliest Miocene time (25-19 Ma), and we infer that megasequence $\mathrm{Y}$ has similar composition and internal structural style to the East Coast Allochthon.

[39] While it is not our preferred interpretation, we cannot rule out the possibility that onshore and offshore allochthons were emplaced as separate entities at slightly different times. If this were the case, then we speculate that the onshore allochthon was emplaced slightly earlier. This is based upon the identification of reflectors downlapping northward onto a sequence boundary directly beneath megasequence $\mathrm{Y}$ (Figure 8) that could be interpreted as a synemplacement deposit associated with allochthonous rocks exposed onshore at Matakaoa Point. Such a correlation would make it geometrically easier to explain the extensive area of allochthonous material (Matakaoa Volcanics) exposed near the coast, because the base of the rock unit would be deeper 


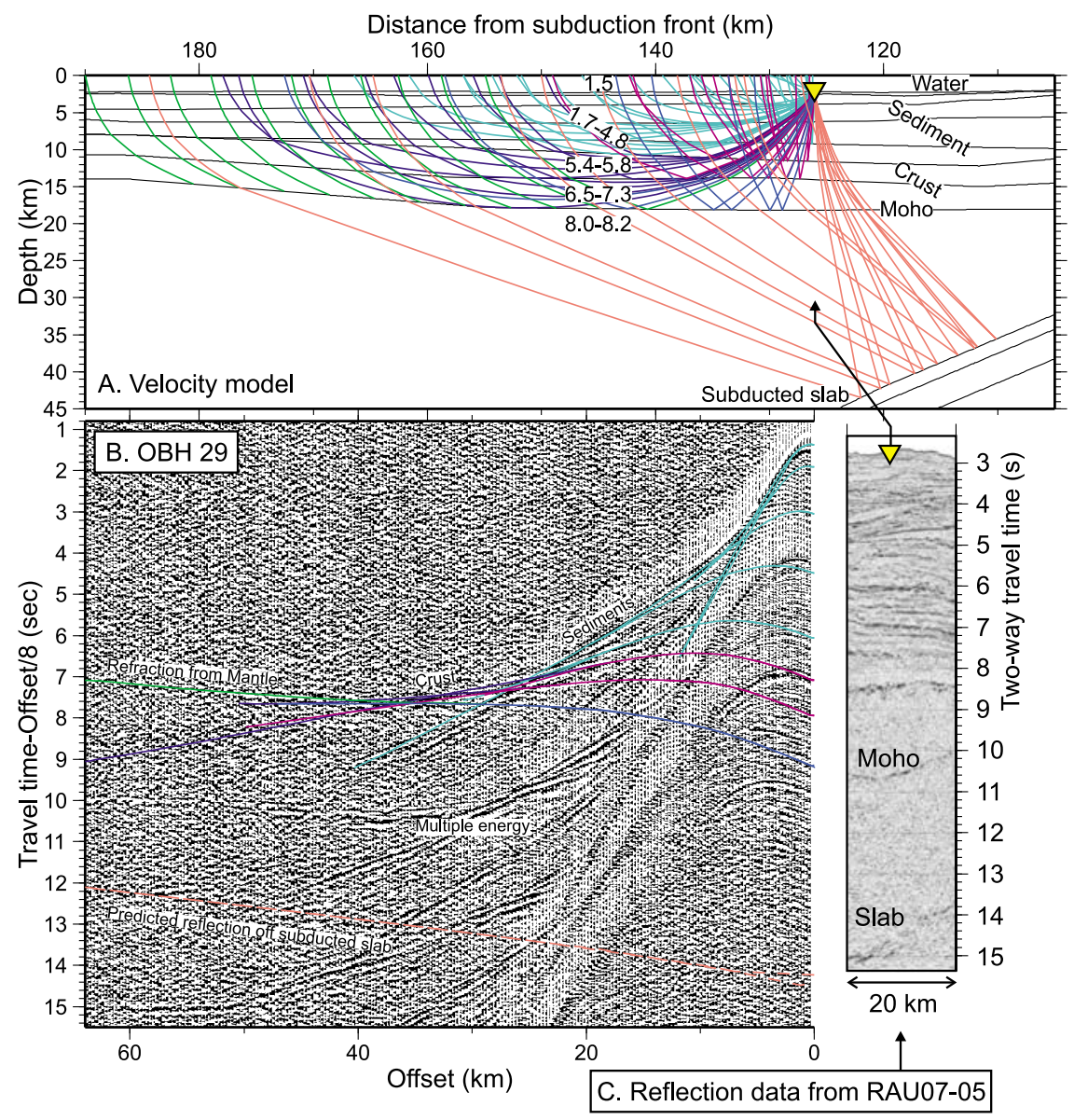

Figure 11. (a) Seismic $\mathrm{p}$ wave velocity $\left(\mathrm{km} \mathrm{s}^{-1}\right)$ model for line RAU07-05, based on (b) receiver gather for OBH 29, which was the most western instrument deployed on voyage SO192 (see Figures 5 and 7) and has modeled arrivals indicated by colored lines. (c) Also shown is a section of the normal incidence CDP-stacked reflection record of line RAU07-05.

within the dipping stratigraphic sequence if it were emplaced earlier.

[40] It follows from our correlation of megasequence $Y$ with the East Coast Allochthon that megasequence $\mathrm{Z}$ is correlative with Neogene fore-arc marine sandstones, siltstones, and mudstones (Tolaga and Mangaheia groups). It similarly follows that the upper part of megasequence $\mathrm{X}$ correlates with clay-rich and calcareous Paleogene mudstones (Mangatu Group). We infer a thicker Neogene sequence than a previous interpretation of line OGS90 [Davey et al., 1997]; we reinterpret strata overlying a prominent angular unconformity on East Cape Ridge on line OGS90 as being within the Neogene sequence.

[41] We suggest that the angular unconformity mapped onshore that separates Cretaceous syntectonic fore arc and trench slope sediments (Matawai Group) from passive margin fine-grained sandstones and organic-rich mudstones (Tinui Group) correlates with the base of megasequence X. Our analysis of sedimentary dips measured onshore (Figure 4) supports the proposal that Matawai Group sediments are only likely to be discontinuously imaged, whereas Tinui Group sediments have a similar degree of deformation to
Neogene sediments and should, therefore, be comparably imaged. We cannot rule out a possibility that the unconformity that separates these two groups onshore may be significantly diachronous and that the base of megasequence $\mathrm{X}$ may be significantly older or younger than $85 \mathrm{Ma}$.

\section{Gravity Model}

[42] We have mapped the offshore distribution of significant sedimentary units and propose that there is a dramatic change in crustal structure within the overlying plate of the Hikurangi subduction zone north of Raukumara Peninsula. We present a 2-D gravity model along line RAU07-05 (Figure 13), to demonstrate that this independent observation is consistent with: observed topography; sedimentary architecture and the depth to the base of the crust that we have determined; the structure of the subducting Hikurangi Plateau [Davy and Wood, 1994]; and reasonable assumptions of densities for different rock types. While we acknowledge that this is a simplified consideration of the gravity field and ignores 3-D effects or complexity associated with the subducted slab, the size of modeled anomalies 


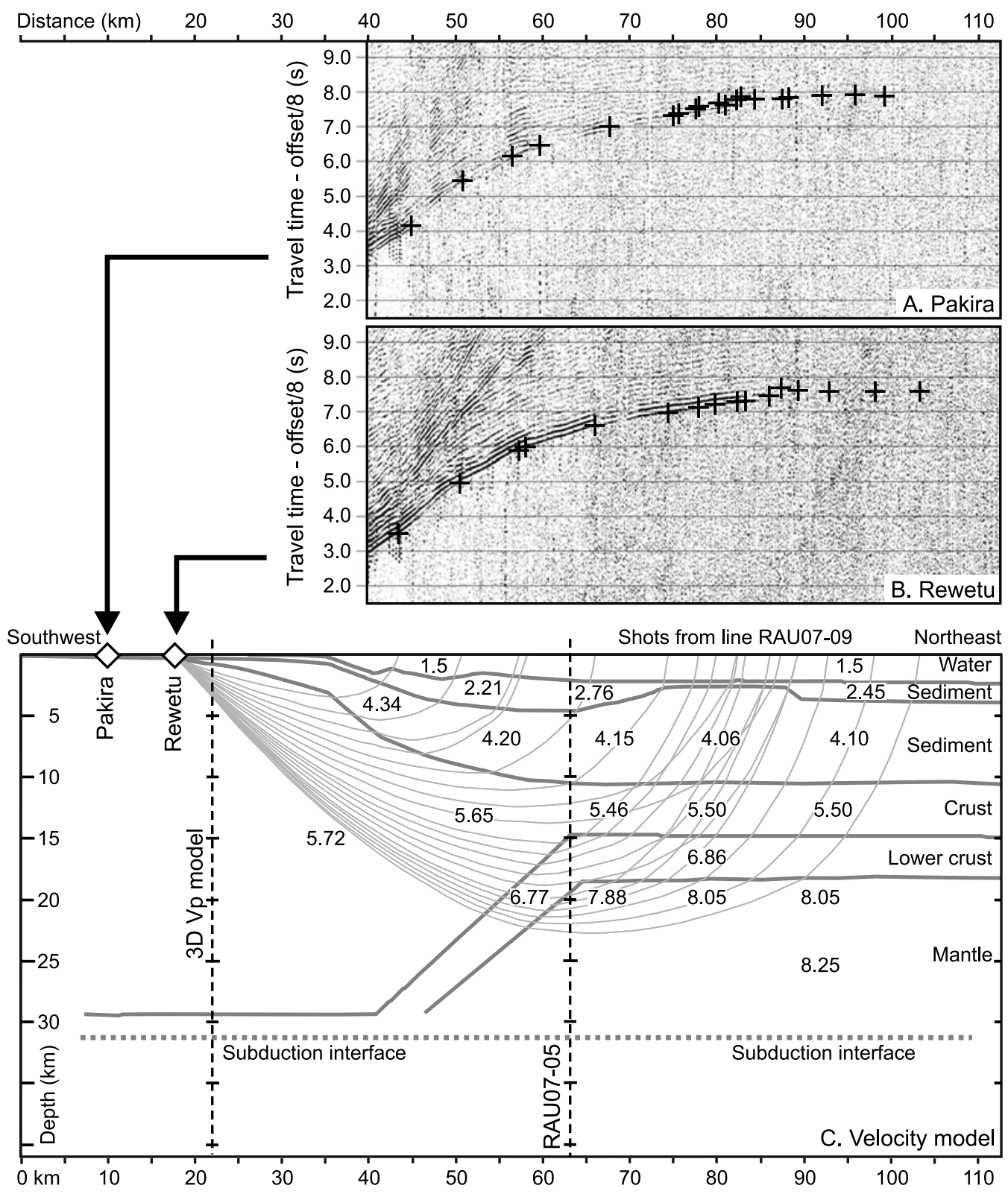

Figure 12. Onshore record of shots from line RAU07-09 and crustal structure model showing seismic velocities $\left(\mathrm{km} \mathrm{s}^{-1}\right)$ and raypaths.

associated with seafloor topography, sediment thickness, and Moho topography in Raukumara Basin are large (>100 mGal), and yet it is clear from Figure 13 that it is straightforward to construct a realistic density model from our crustal model that is consistent with gravity observations. Therefore, we conclude that our crustal model is consistent with the observed gravity field.

\section{Origin and Evolution of Raukumara Basin}

\subsection{Cretaceous Gondwana Convergent Margin (160- $85 \mathrm{Ma})$}

[43] On the basis of seismic character, we identify faultbounded sedimentary units along the western margin of
Raukumara Basin beneath megasequence X; and we correlate these with Cretaceous Matawai and Ruatoria Group marine clastic sediments that are mapped onshore [Mazengarb and Harris, 1994; Mazengarb and Speden, 2000]. In central and eastern parts of the basin, high-amplitude reflections at the top of acoustic basement are inferred as a boundary with crystalline basement rock, and in central parts of the basin, we constrain the underlying crust to have a thickness of just $6-8 \mathrm{~km}$. Hence, we agree with a previous suggestion that crust in the central part of the basin has oceanic or large igneous province character and is possibly correlative to the Hikurangi Plateau [Davey et al., 1997]. We, therefore, interpret the observed geometry as an east verging thrust wedge in the western basin that was emplaced above 


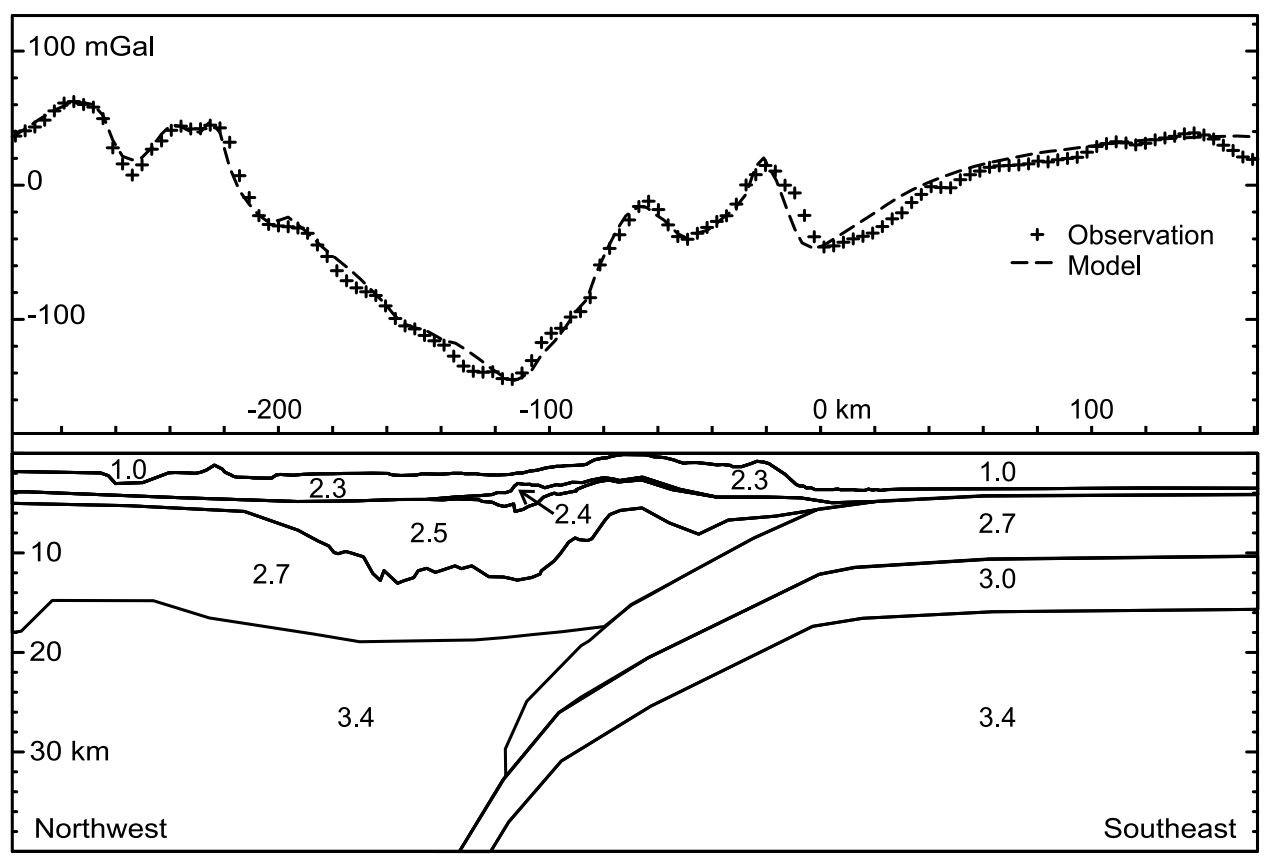

Figure 13. A 2-D gravity model along line RAU07-05 (for location, see Figure 5). Densities are shown in $\mathrm{g} \mathrm{cm}^{-3}$.

subducting oceanic crust in the central and eastern basin. The timing of cessation of Cretaceous deformation has been determined onshore to be at circa $85 \mathrm{Ma}$ [Mazengarb and Harris, 1994].

[44] The tectonic history inferred by us and others [Mazengarb and Harris, 1994; Mazengarb and Speden, 2000] for Raukumara Basin and Peninsula is in marked contrast to that inferred for elsewhere in the New Zealand, eastern Australia, and Antarctic regions. The cessation of Gondwana arc-related volcanism in the New Zealand sector of Gondwana was complete by circa $105 \mathrm{Ma}$ and during the interval 105-85 Ma there was widespread rift basin development (e.g., Taranaki, Great South, and Gippsland basins; Figure 14) [Cook et al., 1999; King and Thrasher, 1996; Laird, 1993; Mortimer et al., 1999; Waight et al., 1998]. By 83-79 Ma, rifts along the southern margin of New Zealand had progressed to seafloor spreading and an isolated continent was created [Gaina et al., 1998; Sutherland, 1999]. We suggest that eastern parts of Raukumara Basin preserve the Cretaceous Gondwana trench slope (Figure 14), and that this geological setting was unlike the adjacent rifted continent and was a proximal cause for the basin's atypical Cretaceous tectonic history and lack of normal-faulted basins.

\subsection{Cretaceous and Paleogene Passive Margin (85- 25 Ma)}

[45] After cessation of Cretaceous tectonics and separation from Gondwana, most of New Zealand subsided passively, while restricted areas still underwent minor extensional faulting [Cook et al., 1999; King and Thrasher, 1996; Laird, 1993]. It is likely that the regional physiography of
New Zealand during this interval was primarily inherited from the previous Cretaceous tectonic phase, with broad subsidence leading to progressive flooding of the land area. Raukumara Basin lay on the northern marine margin of New Zealand throughout this interval of northward drift (Figure 14).

[46] We correlate megasequence $\mathrm{X}$ with this phase of passive margin deposition. It is clear from the isopach map (Figure 9) that Raukumara Basin was a significant depocenter during this interval, and this was probably a consequence of its anomalous Cretaceous tectonic history. The total sediment thickness for this interval $(\sim 5-8 \mathrm{~km})$ is one of the greatest known from the New Zealand region. This observation is significant for interpretations of past environment and sedimentary facies: it may be that there was an indentation in the margin and inherited structural control of onshore sediment pathways toward the depocenter.

[47] Although megasequence $\mathrm{X}$ was continuously deposited in a passive setting until circa $25 \mathrm{Ma}$, activity at the Australia-Pacific boundary started north and south of New Zealand at circa 45 Ma [Sutherland, 1995]. Rift basins of southern New Zealand were the manifestation of an extensional plate boundary that increased in extension rate farther south, where seafloor spreading was developed [Lamarche et al., 1997; Sutherland, 1995; Wood et al., 1996]. The occurrence of smectite-rich clays in Eocene-Oligocene sediments of Raukumara Peninsula may reflect the distal onset of arc volcanism and subduction to the north. It may be that open folding of the lower part of megasequence $\mathrm{X}$ along the western basin margin is related to reactivation of Cretaceous thrust faults during the Eocene onset of subduction north of New Zealand. 

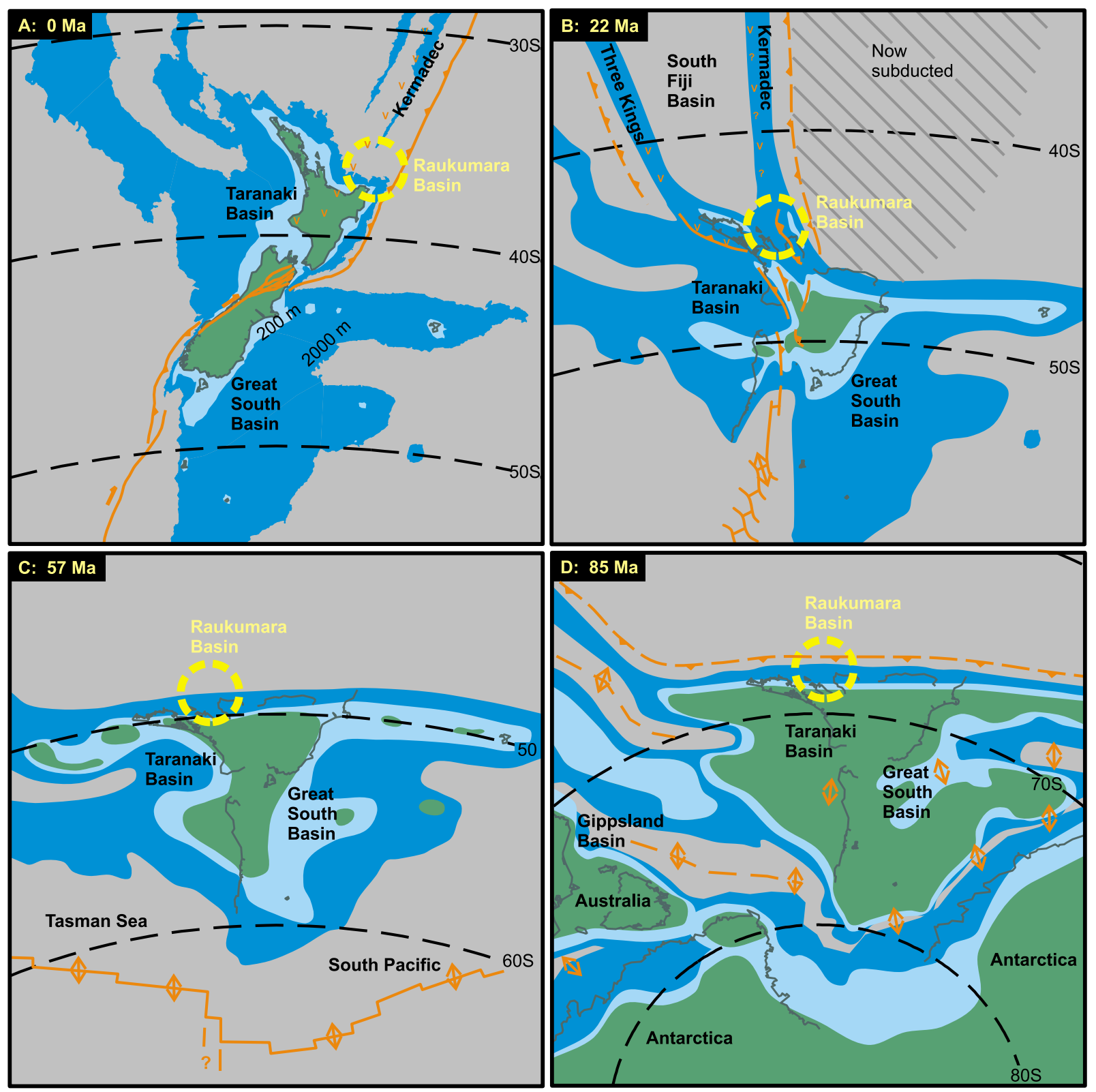

Figure 14. Tectonic evolution of Raukumara Basin. (a) Present tectonic setting with plate boundary shown in orange and the active volcanic chain marked (v). (b) Immediately after emplacement of allochthonous material into Raukumara Basin (megasequence $\mathrm{Y}$ ) and the establishment of the modern Kermadec subduction system. (c) Passive margin deposition corresponding to megasequence X. (d) The end of Gondwana margin tectonics and establishment of the architecture of western Raukumara Basin.

\subsection{Subduction Initiation and Allochthon Emplacement (25-19 Ma)}

[48] There was a significant change in Australia-Pacific plate motions during the interval $30-20 \mathrm{Ma}$ [Cande and Stock, 2004] that led to the onset of subduction beneath northern New Zealand. The oldest arc-related calc-alkaline volcanoes are dated at circa 24-22 Ma [Herzer, 1995], and the onset of subduction was accompanied by emplacement of large-scale allochthonous sheets [Brothers and Delaloye,
1982; Field and Uruski, 1997; Isaac et al., 1994; Mazengarb and Speden, 2000; Rait et al., 1991; Stoneley, 1968]. We identify and map an allochthonous unit within Raukumara Basin (megasequence Y) that correlates in character, stratigraphic position, and is approximately geometrically continuous with the East Coast Allochthon.

[49] We interpret the wedge-shaped unit within acoustic basement beneath the western limb of the basin (labeled W in Figure 6) to be the Cretaceous Gondwana fore arc, but we see no evidence for Cenozoic reactivation of the Cretaceous 
subduction thrust. We suggest that this is a key observation and implies that Cenozoic subduction thrust evolution and linkage did not require reactivation of the structure. This resulted in the unique preservation of Raukumara Basin, but it is not possible to more fully understand the reasons for basin preservation without a regional consideration of Tonga-Kermadec-Hikurangi subduction zone evolution, which is outside the scope of this paper.

\subsection{Neogene Fore Arc Basin (22-0 Ma)}

[50] Megasequence $Z$ represents the fore-arc basin fill associated with Neogene development of the modern Hikurangi-Kermadec subduction system. Multiple sequence boundaries can be recognized within the basin and it is outside the scope of this work to describe those in more detail, but we speculate briefly below on some of the processes and regional events that may ultimately be the cause of significant sequence boundaries within the basin.

[51] Regional changes in subduction geometry may reflect evolution of slab and back-arc geometries at scales $>100 \mathrm{~km}$. It has been suggested that at circa $12 \mathrm{Ma}$ the current Kermadec trend of arc volcanoes propagated southward into central North Island [Herzer, 1995]. In Coromandel Peninsula, andesitic volcanism of similar chemistry was erupted from circa 18-9 Ma, with a bimodal rhyolite-basalt suite being developed during 9-7 Ma [Adams et al., 1994]. During circa 6-4 Ma, there was a transition to basaltic eruptions at Coromandel Peninsula and then abandonment of those volcanic centers [Adams et al., 1994]; this transition coincides with when it is thought that spreading initiated in the southern Havre Trough, though the spreading center may have progressively stepped eastward to maintain some optimal position with respect to the subduction zone [Wright et al., 1996]. It is likely that key sequence boundaries within the basin may relate to these tectonic and volcanic changes, convolved with regional sea level and oceanographic change.

[52] The most obvious manifestations of subductionrelated deformation are restricted to the eastern margin of Raukumara Basin, near East Cape Ridge (Figures 7 and 10). The width of the zone of uplift, faulting and slope failures is $50-100 \mathrm{~km}$. Therefore, given that subduction rates during Neogene time in this region have been $40-60 \mathrm{~km} / \mathrm{Myr}$, it is expected that responses within the overriding plate will be significant at timescales of $\sim 1-2 \mathrm{Myr}$, as the nature and geometry of the slab is replaced. We observe a complex stratigraphy of unknown age along the eastern margin of the basin and infer that subduction zone processes are responsible.

\section{Cenozoic Plate Boundary Kinematics}

[53] The seismic reflection data set indicates that Raukumara Basin has suffered little internal deformation, except at its eastern and western edges, and has no major deep-seated faults that offset latest Cretaceous and Paleogene strata. Therefore, the basin represents a relatively rigid block within an active plate boundary system that otherwise contains extensive distributed deformation [Beavan and Haines, 2001; Walcott, 1986].
[54] Onshore, paleomagnetic declination anomalies indicate that northern Raukumara Peninsula has rotated, relative to mean magnetic north (and hence the spin axis of Earth), at a rate similar to that predicted by Australian plate motion [Mumme et al., 1989; Rowan and Roberts, 2005, 2008]. At the southern margin of Raukumara Basin, strata are gently tilted upward toward the land but are not offset by major faults (Figure 8). Therefore, we suggest that Raukumara Basin is part of the northern Raukumara fore-arc block that has moved with the Australian plate, and has been translated away from it by extension in the Havre Trough; but this block has not undergone any significant relative rotation about a local rotation pole since $22-19 \mathrm{Ma}$, as is observed farther south in eastern North Island [Mumme et al., 1989; Roberts, 1992; Rowan and Roberts, 2005, 2008; Thornley, 1997; Walcott et al., 1981].

\section{Allochthon Emplacement Direction}

[55] It was previously proposed, on the basis of observations in southern and central onshore regions of the East Coast Allochthon [Kenny, 1984; Rait et al., 1991; Stoneley, 1968], that emplacement direction was toward the southwest. However, we have mapped the thinned frontal edge and tip line of the offshore allochthon (megasequence Y) and find that it trends northeast-southwest over a distance of $100-150 \mathrm{~km}$ (Figure 9). Sediments at the base of the overlying megasequence $\mathrm{Z}$ downlap and thicken toward the west or northwest. Therefore, we conclude that, although the local emplacement direction near the southern edge of the East Coast Allochthon may have been toward the southwest, the regional direction of allochthon emplacement was toward the west or northwest.

\section{Local Tectonic Erosion and Underplating of the Crust}

[56] The geometry of reflectors within Raukumara Basin constrains mass balance at the fore arc over the past $22 \mathrm{Myr}$ of subduction. If there had been net tectonic erosion at the subduction interface that had moved and mixed fore-arc crust into the mantle then ancient arc volcanoes should be preserved in the western part of Raukumara Basin, because the entire fore arc would be advected trenchward if the volcano-trench distance remained approximately constant. We have no reason to believe that the type of crust being subducted or the angle of subduction has changed significantly during Neogene time, and hence no reason to believe that the trench-arc distance has changed. We observe no fossil volcanoes east of the active arc but are able to image strata of Cretaceous-Paleogene age. Our observations are not consistent with a previous suggestion of trench retreat rate of $1.5 \mathrm{~km} \mathrm{Myr}^{-1}$ (33 km since $22 \mathrm{Ma}$ ), which was used as input to compute global subduction fluxes [Clift and Vannucchi, 2004]. We conclude that large-scale removal of fore-arc material into the mantle by tectonic erosion has not occurred at any time since $22 \mathrm{Ma}$ adjacent to Raukumara Basin. 
[57] Alternatively, if there had been net addition to the fore arc, possibly through crustal accretion of sediment from the downgoing plate, then the volume of the trench slope wedge has increased with time. This would result in progressive broadening of the zone of uplift at the eastern basin margin throughout Neogene time. We see Neogene stratal relationships that are consistent with this hypothesis at both the eastern and southern basin margins, and hence we conclude that this is a possibility. We reconcile the observation that the trench slope consists of highly faulted and indurated rock [Collot and Davy, 1998], rather than accreted sediment, by suggesting that accretion of the $>1 \mathrm{~km}$ thickness of incoming sediment and crustal debris is occurring by underplating of the middle and lower crust after transport downward via a subduction channel.

[58] It has previously been suggested that the relatively high topography of Raukumara Peninsula is the result of Neogene crustal underplating caused by subduction processes [Walcott, 1987]. This view is supported by earthquake tomographic studies that image a deep $(\sim 40 \mathrm{~km})$ crustal root beneath Raukumara Peninsula that is associated with low $\mathrm{Q}_{\mathrm{p}}$ and high $\mathrm{V}_{\mathrm{p}} / \mathrm{V}_{\mathrm{s}}$ [Eberhart-Phillips and Chadwick, 2002; Reyners et al., 1999]. The plate interface beneath Raukumara Peninsula is shown from converted seismic waves to be characterized by a $1-2 \mathrm{~km}$ thick layer with anomalously low $\mathrm{V}_{\mathrm{p}}$ of 5.0-5.4 $\mathrm{km} \mathrm{s}^{-1}$ and high $\mathrm{V}_{\mathrm{p}} / \mathrm{V}_{\mathrm{s}}$ of 2.0; this weak layer is inferred to be a channel of actively subducting or underplating sediment [Eberhart-Phillips and Reyners, 1999]. The continuing long-wavelength uplift of Raukumara Peninsula, combined with other observations, is shown by numerical models to be consistent with the underplating hypothesis, rather than crustal thickening by shortening across faults [Litchfield et al., 2007; Upton et al., 2003].

[59] Our study allows us to compare Raukumara Peninsula with the region farther north, where fore-arc crustal thickness is much less. We infer a long-lived depocenter in Raukumara Basin from the geometry of megasequence $\mathrm{X}$ and hence the crustal thickness beneath Raukumara Basin has been less than that of Raukumara Peninsula since Late Cretaceous time. This is consistent with the oceanic crust type inferred from seismic reflection character, thickness and $\mathrm{p}$ wave refraction velocities. The character of the trench slope and fill is similar in both regions, so it is reasonable to infer that similar processes are occurring on the shallow subduction interface and that the trench slope materials and processes are similar. We determine a depth to the Moho beneath Raukumara Basin of $\sim 17 \mathrm{~km}$ and observe that the subduction interface has a depth of $\sim 10-15 \mathrm{~km}$ beneath East Cape Ridge. In contrast, the crustal thickness of Raukumara Peninsula is $\sim 35-40 \mathrm{~km}$ and the subduction interface has a depth of $\sim 30-40 \mathrm{~km}$ beneath the Raukumara Range. The intersection between the Moho and the subduction thrust correlates spatially with where crustal underplating occurs (Figure 15). Therefore, it appears that existing crustal thickness plays a key role in determining the depth to which crustal material can be transported down a subduction channel.
[60] Based upon the observed crustal character and geometry (above), we suggest a cyclical process of: sediment and crust are faulted into a "subduction channel" at the subduction thrust; material within the subduction channel is transported arcward and downward; this material is then underplated near the base of the crust where it is thermally weakened and of much lower density than the deeper mantle wedge; crustal underplating drives local rock uplift; which causes steepening of the trench slope above its critical angle of stability and results in collapse of material back toward the subduction front (Figure 15).

[61] If the underplating rate was the same beneath East Cape Ridge and Raukumara Peninsula, then more rapid collapse of the trench slope adjacent to East Cape Ridge would be expected, because East Cape Ridge is closer to the subduction front than Raukumara Peninsula so the slope angle would be increased more rapidly by the same uplift rate. This is consistent with general observations of the intensity of faulting of the trench slope adjacent to East Cape Ridge, but we have insufficient data to quantify alongstrike variation in rock uplift rate and geometry.

\section{Implications for Growth and Recycling of Continental Crust}

[62] Subduction margins play a key role in generating new continental crust through igneous activity at arcs, recycling crust by accretion of continent-derived sediment, and they are the most obvious locations where continental crust could be mixed back into the mantle. It is, therefore, important but extremely difficult to directly quantify these fluxes through the direct measurement of observable products: arcs, accretionary wedges, and trench slope subsidence histories.

[63] A highly cited study of seismic profiles through arcs of known (estimated) Phanerozoic activity led to a global arc growth rate estimate of $1.65 \mathrm{~km}^{3} \mathrm{yr}^{-1}$ [Reymer and Schubert, 1984]. Uncertainties in this study are unquantified: material may have escaped measurement because it was not identified (e.g., it was eroded or erupted to form sediment); or may have been incorrectly included in the calculation even though it was older than the time period being explicitly considered. The study is significant for our discussion because geochemical and freeboard arguments require that the rate of crustal growth and remixing of crustal material back into the mantle have been approximately similar during Phanerozoic time, with a slight net growth of continents implied [Clift and Vannucchi, 2004; Dewey and Windley, 1981; Reymer and Schubert, 1984; VonHuene and Scholl, 1991].

[64] Estimates of the flux of subducted sediment and continental material have increased as additional data have become available from 0.6 to $1.0 \mathrm{~km}^{3} \mathrm{yr}^{-1}$ [Dewey and Windley, 1981], to $1.3-1.8 \mathrm{~km}^{3} \mathrm{yr}^{-1}$ [VonHuene and Scholl, 1991], to $3.9 \mathrm{~km}^{3} \mathrm{yr}^{-1}$ [Clift and Vannucchi, 2004]. The primary reason for the progressive increase in this estimate arises from the recognition of trench slope regions that are not composed of young accreted sediment and that have subsided rapidly during subduction activity. Trench slope 

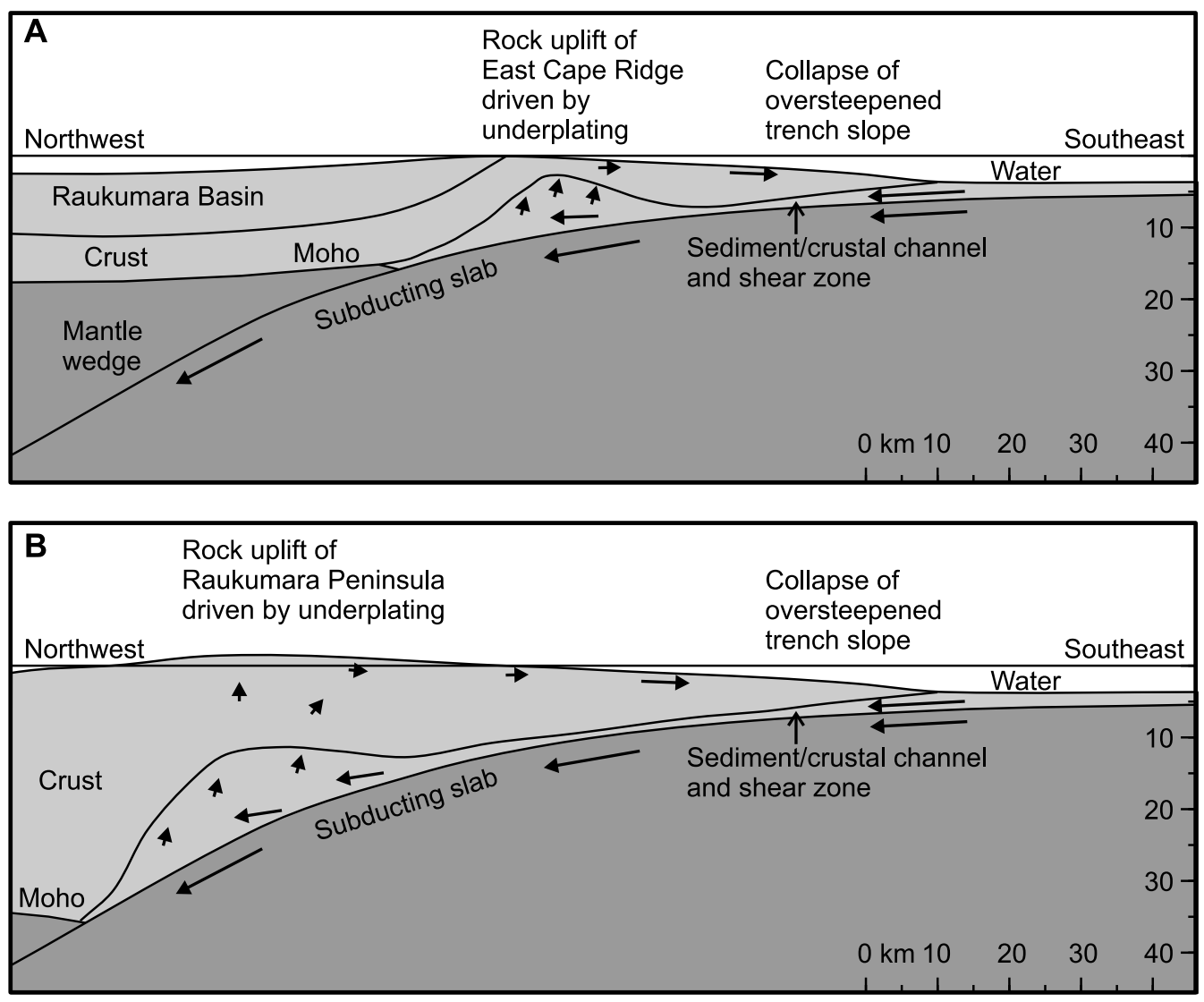

Figure 15. Cartoon showing rock uplift causing oversteepening and collapse of the trench slope; then collapsed material and incoming sediment is translated down a "subduction channel" and underplated to the lower crust, causing further uplift. The locus of uplift is closer to the subduction front (a) in Raukumara Basin than (b) at Raukumara Peninsula, where the crust is thicker; leading us to suggest that the Moho is a fundamental control on underplating processes.

subsidence values are typically converted to tectonic erosion values assuming constant average wedge taper through time and vertical rock trajectories as the base of the wedge is removed by subduction erosion [Clift and Vannucchi, 2004].

[65] Previous global subduction budgets have included our study region as one of net subduction erosion [Clift and Vannucchi, 2004; VonHuene and Scholl, 1991], based upon evidence for frontal tectonic erosion, subsidence and collapse of the trench slope. We agree with the observations that were used, but propose an alternative interpretation that involves no net loss in volume of the fore arc.

[66] To satisfy all of our observations, we propose a cyclical crustal kinematic within the fore arc: material is tectonically eroded at the toe of the trench slope; it is moved down a subduction channel to near the base of the crust; underplating near the Moho causes rock uplift and steepening of the trench slope; which in turn causes extension, subsidence, and collapse of the slope toward the trench; and material falls back into the subduction channel and completes the cycle. Material may be added from the incoming plate or lost into the mantle, but it is also possible for the fore arc to establish a geometrical dynamic equilibrium where there is no net change in volume or shape of the fore arc, but the cyclical rock particle paths lead to persistent collapse and subsidence of the trench slope. Hence, estimates of fore-arc loss based upon trench slope subsidence may systematically overestimate the rate that crustal material is mixed into the mantle.

[67] Our hypothesis is supported by numerical and analog models. Previous theoretical considerations of subduction erosion have shown that it is straightforward to reproduce a subduction channel moving with the subducted plate within the crust [Lallemand et al., 1994], but density contrasts between crust and mantle can result in underplating at the base of the crust [Ellis et al., 1999], or a return flow of crustal material from greater depths within the subduction system back upward to the crust [Gerya et al., 2002]. Our hypothesis is also supported by geochemical data. For example, the flux of young subducted sediment into Tongan lavas [George et al., 2005] is much less than predicted by simple models of trench slope subsidence [Clift and MacLeod, 1999].

[68] Our conclusion that subsidence rates measured on trench slopes systematically overestimate the rate of removal of crustal material into the mantle implies that aggregate 
global estimates are too high. We submit that the true uncertainties involved in making estimates of crustal growth and loss based upon direct measurement of arc and fore-arc volumes through time remain sufficiently large that it is still difficult to use these data to draw robust conclusions about the net growth and recycling rate of continental crust during Phanerozoic time.

\section{Conclusions}

[69] New seismic reflection and refraction data allow us to identify and map Raukumara Basin (Figures 1, 4, and 9) and determine the crustal architecture of part of the Hikurangi fore-arc region. Raukumara Basin has a maximum of $\sim 12 \mathrm{~km}$ sediment thickness and we recognize three seismic reflection megasequences (Figures 6, 7, and 8) that we correlate with onshore lithostratigraphic units (Figures 2 and 3): X, a Late Cretaceous and Paleogene marine passive margin megasequence; Y, a sheet of allochthonous material that we interpret as a large submarine landslide emplaced during the onset of subduction beneath East Cape Ridge at circa $21 \mathrm{Ma}$; and Z, a Neogene subduction margin marine megasequence (Figure 14).

[70] The base of the crust is shown to lie at $\sim 17 \mathrm{~km}$ beneath the center of the basin, but the crust thickens southward and the base of the crust lies at $\sim 35 \mathrm{~km}$ beneath Raukumara Peninsula (Figures 11, 12, and 13). Beneath the western basin margin, we recognize reflective units that we interpret to be deformed sediment of the Gondwana fore arc that was thrust in Cretaceous time over oceanic crust with a thickness of $\sim 7 \mathrm{~km}$. West dipping reflection events at $13-$ $15 \mathrm{~s}$ twt are interpreted as the active subduction thrust lying at $\sim 35 \mathrm{~km}$ beneath the basin center (Figures 7 and 11).

[71] Raukumara Basin has normal faults at its western margin and is broadly uplifted along its eastern and southern margin, but is only weakly deformed over most of its area (Figure 10). Hence, we infer that Raukumara Peninsula and Basin have behaved as a large $(>150 \mathrm{~km}$ long) and relatively rigid fore-arc block that has been translated from the Australian plate by spreading in the Havre Trough; this conclusion is in contrast to large Neogene vertical axis rotations that have been inferred on the basis of paleomagnetic data from the Hikurangi fore arc farther south [Mumme et al., 1989; Roberts, 1992; Rowan and Roberts, 2005, 2008; Thornley, 1997; Walcott et al., 1981].

[72] We infer that initial uplift of East Cape Ridge was associated with subduction initiation in latest Oligocene or early Miocene time and resulted in the emplacement of a large $\left(\sim 10,000 \mathrm{~km}^{3}\right)$ submarine landslide westward or northwestward into the basin (megasequence Y). Kinematic indicators from correlative onshore allochthonous rocks indicate southwestward movement [Kenny, 1984; Rait et al., 1991; Stoneley, 1968], but we suggest that this conclusion cannot be generalized to the entire $>200 \mathrm{~km}$ strike length of allochthonous rocks, because the general westward taper of the western edge of the allochthonous sheet and the westward downlap of immediately overlying strata in Raukumara Basin suggests a westward or northwestward paleoslope and emplacement direction (Figures 6, 8, and 9).

[73] The lack of fossil arc volcanoes in the western basin and broadening of the zone of uplift in the eastern basin lead us to conclude that net crustal accretion to the fore arc has occurred during Neogene time. However, the many small faults that are evident on swath bathymetry and seismic reflection data from the trench slope and the lack of coherent internal reflections beneath the trench slope indicate collapse of indurated rock, rather than accretion of sediment from the downgoing plate. We infer fore-arc accretion by crustal underplating, which drives rock uplift beneath East Cape Ridge. We conclude that the underplating process is modulated by crustal thickness, because we observe the locus of uplift to be spatially correlated with the intersection between the Moho and subduction thrust: uplift of Raukumara Peninsula is $\sim 110 \mathrm{~km}$ from the subduction front where the Moho is at $\sim 35 \mathrm{~km}$ depth; and uplift of East Cape Ridge is $\sim 60 \mathrm{~km}$ from the subduction front where the Moho is at $\sim 17 \mathrm{~km}$ depth (Figure 15).

[74] We propose a cyclical fore-arc kinematic: rock moves down a subduction channel to near the base of the crust, where underplating drives rock uplift and oversteepens the trench slope, causing collapse back toward the trench and subduction channel. The cyclical rock particle paths lead to persistent collapse and subsidence of the trench slope, and hence existing estimates of fore-arc loss based upon trench slope subsidence [Clift and Vannucchi, 2004; VonHuene and Scholl, 1991] systematically overestimate the rate that crustal material is mixed into the mantle. We submit that the true uncertainties in direct measurement of arc and fore-arc volumes through time remain sufficiently large that it remains a substantial challenge to draw robust conclusions about the net global growth rate of continental crust during Phanerozoic time.

[75] Acknowledgments. We thank Kip Hodges; Margi Rusmore, and two anonymous reviewers. Primary funding for this work was from the New Zealand Ministry of Economic Development and the Foundation for Research Science and Technology. Refraction data were collected by R/V Sonne and analysis by German coauthors was funded by BMBF grant 03G0192C. The RAU07 data set was acquired by CGG Veritas Marine using vessel CGG Duke and processed by Fugro Seismic Imaging. The $05 \mathrm{CM}$ data set was acquired by Multiwave using the vessel Pacific Titan and was processed by GNS Science and Fugro Seismic Imaging.

\section{References}

Adams, C. J., I. J. Graham, D. Seward, and D. N. B. Skinner (1994), Geochronological and geochemical evolution of late Cenozoic volcanism in the Coromandel Peninsula, New Zealand, N. Z. J. Geol. Geophys., 37, 359-379.

Aita, Y., and K. B. Sporli (1992), Tectonic and paleobiogeographic significance of radiolarian microfau- nas in the Permian to Mesozoic basement rocks of the North Island, New Zealand, Palaeogeogr. $\mathrm{Pa}$ laeoclimatol. Palaeoecol., 96, 103-125, doi:10.1016/0031-0182(92)90062-A.

Árnadóttir, T., S. Thornley, F. F. Pollitz, and D. J. Darby (1999), Spatial and temporal strain rate variations at the northern Hikurangi margin, New
Zealand, J. Geophys. Res., 104, 4931-4944, doi:10.1029/1998JB900109.

Beavan, J., and J. Haines (2001), Contemporary horizontal velocity and strain rate fields of the PacificAustralian plate boundary zone through New Zealand, J. Geophys. Res., 106, 741-770, doi:10.1029/ 2000JB900302. 
Brothers, R. N., and M. Delaloye (1982), Obducted ophiolites of North Island, New Zealand: Origin, age, emplacement and tectonic implications for Tertiary and Quaternary volcanicity, N. Z. J. Geol Geophys, 25, 257-274.

Cande, S. C., and J. M. Stock (2004), Pacific-AntarcticAustralia motion and the formation of the Macquarie Plate, Geophys. J. Int., 157, 399-414, doi:10.1111/ j.1365-246X.2004.02224.x.

CANZ (2008), New Zealand region bathymetry, 1:4,000,000, 2nd ed., chart, Misc. Ser. 73, Natl. Inst. of Water and Atmos. Res., Lower Hutt.

Cawood, P. A., A. A. Nemchin, A. Leverenz, A Aseed, and P. F. Balance (1999), U/Pb dating of detrital zircons; implications for the provenance record of Gondwana margin terranes, Geol. Soc. Am. Bull., 111, 1107-1119, doi:10.1130/0016 7606(1999) $111<1107:$ UPDODZ $>2.3 . C O ; 2$.

Clift, P. D., and C. J. MacLeod (1999), Slow rates of subduction erosion estimated from subsidence and tilting of the Tonga forearc, Geology, 27(5), 411-414, doi:10.1130/0091-7613(1999)027< 0411:SROSEE $>2.3 . \mathrm{CO} ; 2$

Clift, P., and P. Vannucchi (2004), Controls on tectonic accretion versus erosion in subduction zones: Implications for the origin and recycling of the continental crust, Rev. Geophys., 42, RG2001, doi:10.1029/2003RG000127.

Collot, J. Y., and B. W. Davy (1998), Forearc structures and tectonic regimes at the oblique subduction zone between the Hikurangi Plateau and the southern Kermadec margin, J. Geophys. Res. 103, 623-650, doi:10.1029/97JB02474.

Collot, J. Y., et al. (1996), From oblique subduction to intra-continental transpression: Structures of the southern Kermadec-Hikurangi margin from multibeam bathymetry, side-scan sonar and seismic reflection, Mar. Geophys. Res., 18(2-4), 357-381, doi:10.1007/BF00286085.

Cook, R. A., R. Sutherland, and H. Zhu (1999), Cretaceous-Cenozoic Geology and Petroleum Systems of the Great South Basin, New Zealand, Inst. Geol. Nucl. Sci. Monogr., vol. 20, 188 pp., Inst. of Geol. and Nucl. Sci. Ltd., Lower Hutt, New Zealand.

Coombs, D. S., C. A. Landis, R. J. Norris, J. M. Sinton, D. J. Borns, and D. Craw (1976), The Dun Mountain Ophiolite Belt, New Zealand, its tectonic setting, constitution, and origin, with special reference to the southern portion, Am. J. Sci., 276, 561-603.

Crampton, J. S. (1996), Inoceramid Bivalves From the Late Cretaceous of New Zealand, Inst. Geol. Nucl. Sci. Monogr., vol. 14, Inst. of Geol. and Nucl. Sci. Ltd., Lower Hutt, New Zealand.

Crampton, J. S., and P. R. Moore (1990), Environment of deposition of the Maungataniwha Sandstone (Late Cretaceous), Te Hoe River area, western Hawke's Bay, New Zealand, N. Z. J. Geol. Geophys., 33, 333-348.

Crampton, J. S., C. J. Hollis, J. I. Raine, L. Roncaglia, P. Shchioler, C. P. Strong, and G. J. Wilson (2004) Cretaceous, in The New Zealand Geological Timescale, Inst. Geol. Nucl. Sci. Monogr., vol. 22, edited by R. A. Cooper, pp. $103-124$, Inst. of Geol. and Nucl. Sci., Lower Hutt, New Zealand.

Davey, F. J., S. Henrys, and E. Lodolo (1997), A seismic crustal section across the East Cape convergen margin, New Zealand, Tectonophysics, 269, 199-215, doi:10.1016/S0040-1951(96)00165-5.

Davy, B. W., and J.-Y. Collot (2000), The Rapuhia Scarp (northern Hikurangi Plateau): Its nature and subduction effects on the Kermadec Trench, Tectonophysics, 328, 269-295, doi:10.1016/S00401951(00)00211-0

Davy, B., and R. Wood (1994), Gravity and magnetic modelling of the Hikurangi Plateau, Mar. Geol., 118, 139-151, doi:10.1016/0025-3227(94)90117-1.

DeMets, C., R. G. Gordon, D. F. Argus, and S. Stein (1994), Effect of recent revisions to the geomagnetic time scale on estimates of current plate motions, Geophys. Res. Lett., 21, 2191-2194, doi:10.1029/94GL02118. de Ronde, C., E. Baker, G. Massoth, J. Lupton, I. Wright, R. Feely, and R. Greene (2001), Intraoceanic subduction-related hydrothermal venting, Kermadec volcanic arc, New Zealand, Earth Planet Sci. Lett., 193, 359-369, doi:10.1016/S0012821X(01)00534-9.

de Ronde, C., et al. (2007), Submarine hydrotherma activity along the mid-Kermadec Arc, New Zealand Large-scale effects on venting, Geochem. Geophys. Geosyst., 8, Q07007, doi:10.1029/2006GC001495.

Dewey, J. F., and B. F. Windley (1981), Growth and differentiation of the continental-crust, Philos. Trans. R. Soc. London, Ser. A, 301, 189-206, doi:10.1098/rsta.1981.0105.

Eberhart-Phillips, D., and M. Chadwick (2002), Threedimensional attenuation model of the shallow Hikurangi subduction zone in the Raukumara Peninsula, New Zealand, J. Geophys. Res. 107(B2), 2033, doi:10.1029/2000JB000046.

Eberhart-Phillips, D., and M. Reyners (1999), Plate interface properties in the northeast Hikurangi subduction zone, New Zealand, from converted seismic waves, Geophys. J. Int., 26, 2565-2568.

Ellis, S., C. Beaumont, and O. A. Pfiffner (1999), Geodynamic models of crustal-scale episodic tectonic accretion and underplating in subduction zones, J. Geophys. Res., 104, 15,169-15,190, doi:10.1029/ 1999JB900071.

Field, B. D., and C. I. Uruski (1997), CretaceousCenozoic Geology and Petroleum Systems of the East Coast Region, Inst. Geol. Nucl. Sci. Monogr. vol. 19, 301 pp., Inst. of Geol. and Nucl. Sci. Ltd., Lower Hutt, New Zealand.

Gaina, C., D. R. Mueller, J.-Y. Royer, J. Stock, J. L. Hardebeck, and P. Symonds (1998), The tectonic history of the Tasman Sea: A puzzle with 13 pieces, J. Geophys. Res., 103, 12,413-12,433, doi:10.1029/98JB00386.

George, R., S. Turner, J. Morris, T. Plank, C. Hawkesworth, and J. Ryan (2005), Pressure-temperature-time paths of sediment recycling beneath the TongaKennadec arc, Earth Planet. Sci. Lett., 233(1-2), 195-211, doi:10.1016/j.epsl.2005.01.020.

Gerya, T. V., B. Stöckhert, and A. L. Perchuk (2002), Exhumation of high-pressure metamorphic rocks in a subduction channel: A numerical simulation, $\mathrm{Tec}$ tonics, 21(6), 1056, doi:10.1029/2002TC001406.

Gillies, P. N., and F. J. Davey (1986), Seismic reflection and refraction studies of the Raukumara forearc basin, New Zealand, N. Z. J. Geol. Geophys., 29, 391-403.

Herzer, R. H. (1995), Seismic stratigraphy of a buried volcanic arc, Northland, New Zealand and implications for Neogene subduction, Mar. Pet. Geol., 12(5), 511-531, doi:10.1016/0264-8172(95)91506-K

Hollis, C. J., G. R. Dickens, B. D. Field, C. M. Jones, and C. P. Strong (2005), The Paleocene-Eocene transition at Mead Stream, New Zealand; a southern Pacific record of early Cenozoic global change, Palaeogeogr. Palaeoclimatol. Palaeoecol., 215 313-343, doi:10.1016/j.palaeo.2004.09.011.

Isaac, M. J., P. R. Moore, and Y. J. Joass (1991), Tahora Formation: The basal facies of a Late Cretaceous transgressive sequence, northeastern New Zealand, N. Z. J. Geol. Geophys., 34, 227-236.

Isaac, M. J., R. H. Herzer, F. J. Brook, and B. W. Hayward (1994), Cretaceous and Cenozoic Sedimentary Basins of Northland, New Zealand, Inst Geol. Nucl. Sci. Monogr., vol. 8, 230 pp., Inst. of Geol. and Nucl. Sci. Ltd., Lower Hutt, New Zealand.

Kamp, P. J. J. (1999), Tracking crustal processes by FT thermochronology in a forearc high (Hikurang margin, New Zealand) involving Cretaceous subduction termination and mid-Cenozoic subduction initiation, Tectonophysics, 307, 313-343, doi:10.1016/S0040-1951(99)00102-X.

Kenny, J. A. (1984), Stratigraphy, sedimentology and structure of the Ihungia decollement, Raukumara Peninsula, North Island, New Zealand, $N$. Z. $J$. Geol. Geophys., 27, 1-19.

Killops, S. D., C. J. Hollis, H. E. G. Morgans, R. Sutherland, B. D. Field, and D. A. Leckie
(2000), Paleoceanographic significance of late Paleocene dysaerobia at the shelf/slope break around New Zealand, Palaeogeogr. Palaeoclimatol. $\mathrm{Pa}$ laeoecol., 156, 51-70, doi:10.1016/S00310182(99)00131-5.

King, P. R., and G. P. Thrasher (1996), CretaceousCenozoic Geology and Petroleum Systems of the Taranaki Basin, New Zealand, Inst. Geol. Nucl. Sci. Monogr., vol. 13, 243 pp., Inst. of Geol. and Nucl. Sci. Ltd., Lower Hutt, New Zealand.

Laird, M. G. (1993), Cretaceous continental rifts: New Zealand region, in Sedimentary Basins of the World, vol. 2, South Pacific Sedimentary Basins, edited by P. F. Balance, pp. 37-49, Elsevier, Amsterdam.

Lallemand, S. E., P. Schnurle, and J. Malavieille (1994), Coulomb theory applied to accretionary and nonaccretionary wedges: Possible causes for tectonic erosion and or frontal accretion, J. Geophys. Res., 99, 12,033-12,055, doi:10.1029/ 94JB00124.

Lamarche, G., J. Y. Collot, R. A. Wood, M. Sosson, R. Sutherland, and J. Delteil (1997), The OligoMiocene Pacific-Australia plate boundary, south of New Zealand: Evolution from oceanic spreading to strike-slip faulting, Earth Planet. Sci. Lett., 148, 129-139, doi:10.1016/S0012-821X(97)00026-5.

Lamarche, G., P. M. Barnes, and J. M. Bull (2006), Faulting and extension rate over the last 20,000 years in the offshore Whakatane Graben, New Zealand continental shelf, Tectonics, 25, TC4005, doi:10.1029/2005TC001886.

Lamarche, G., C. Joanne, and J.-Y. Collot (2008), Successive, large mass-transport deposits in the south Kermadec fore-arc basin, New Zealand: The Matakaoa Submarine Instability Complex, Geochem. Geophys. Geosyst., 9, Q04001, doi:10.1029/ 2007GC001843.

Lillie, A. R. (1953), The geology of the Dannevirke subdivision, N. Z. Geol. Surv. Bull., 46, 1-156.

Litchfield, N., S. Ellis, K. Berryman, and A. Nicol (2007), Insights into subduction-related uplift along the Hikurangi Margin, New Zealand, using numerical modeling, J. Geophys. Res., 112, F02021, doi:10.1029/2006JF000535.

Mazengarb, C., and D. H. M. Harris (1994), Cretaceous stratigraphic and structural relationships of Raukumara Peninsula, New Zealand; stratigraphic patterns associated with the migration of a thrust system, Ann. Tectonicae, 8(2), 100-118.

Mazengarb, C., and I. G. Speden (2000), Geology of the Raukumara area, 1:250,000 Geol. Map 6, 60 pp., Inst. of Geol. and Nucl. Sci. Ltd., Lower Hutt, New Zealand.

Moore, P. R. (1988a), Stratigraphy, composition, and environment of deposition of the Whangai Formation and associated Late Cretaceous-Paleocene rocks, eastern North Island, New Zealand, $N$. Z . Geol. Surv. Bull., 100, 1-82.

Moore, P. R. (1988b), Structural subdivisions of eastern North Island, N. Z. Geol. Surv. Rec., 30, 1-24.

Moore, P. R. (1989), Stratigraphy of the Wipawa black shale (Paleocene), eastern North Island, New Zealand, N. Z. Geol. Surv. Rep., 38, 1-19.

Moore, P. R., A. G. Adams, M. J. Isaac, C. Mazengarb, H. E. G. Morgans, and C. J. Phillips (1986), A revised Cretaceous-early Tertiary stratigraphic nomenclature for eastern North Island, N. Z. Geol. Surv. Rep., G104.

Mortimer, N. (1994), Origin of the Torlesse Terrane and coeval rocks, North Island, New Zealand, Int. Geol. Rev., 36,891-910, doi:10.1080/ 00206819409465494

Mortimer, N., and D. Parkinson (1996), Hikurangi Plateau: A Cretaceous large igneous province in the southwest Pacific Ocean, J. Geophys. Res., 101, 687-696, doi:10.1029/95JB03037.

Mortimer, N., A. J. Tulloch, R. N. Spark, N. W. Walker, E. Ladley, A. Allibone, and D. L. Kimbrough (1999), Overview of the Median Batholith, New Zealand: A new interpretation of the geology of the Median Tectonic Zone and adjacent rocks, $J$ 
Afr. Earth Sci., 29(1), 257-268, doi:10.1016/ S0899-5362(99)00095-0.

Mumme, T. C., S. H. Lamb, and R. I. Walcott (1989), The Raukumara paleomagnetic domain: Constraints on the tectonic rotation of the east coast, North Island, New Zealand, from paleomagnetic data, N. Z. J. Geol. Geophys., 32, 317-326.

Nicol, A., and L. M. Wallace (2007), Temporal stability of deformation rates: Comparison of geological and geodetic observations, Hikurangi subduction margin, New Zealand, Earth Planet. Sci. Lett., 258(3-4), 397-413, doi:10.1016/j.eps1.2007.03.039.

Nicol, A., C. Mazengarb, F. Chanier, G. Rait, C. I Uruski, and L. M. Wallace (2007), Tectonic evolution of the active Hikurangi subduction margin, New Zealand, since the Oligocene, Tectonics, 26 , TC4002, doi:10.1029/2006TC002090.

Rait, G., F. Chanier, and D. W. Waters (1991), Landwardand seaward-directed thrusting accompanying the onset of subduction beneath New Zealand, Geol$o g y, 19(3), 230-233$, doi:10.1130/0091 7613(1991)019<0230:LASDTA $>2.3 . \mathrm{CO} \cdot 2$.

Reymer, A., and G. Schubert (1984), Phanerozoic addition rates to the continental-crust and crustal growth, Tectonics, 3, 63-77, doi:10.1029/ TC003i001p00063.

Reyners, M., and P. McGinty (1999), Shallow subduction tectonics in the Raukumara Peninsula, New Zealand, as illuminated by earthquake focal mechanisms, J. Geophys. Res., 104, 3025-3034, doi:10.1029/1998JB900081.

Reyners, M., D. Eberhart-Phillips, and G. Stuart (1999), A three-dimensional image of shallow subduction: Crustal structure of the Raukumara Peninsula, New Zealand, Geophys. J. Int., 137, $873-$ 890, doi:10.1046/j.1365-246x.1999.00842.x.

Roberts, A. P. (1992), Paleomagnetic constraints on the tectonic rotation of the southern Hikurangi margin, New Zealand, N. Z. J. Geol. Geophys., $35,311-323$.

Rowan, C. J., and A. P. Roberts (2005), Relocation of the tectonic boundary between the Raukumara and Wairoa Domains (East Coast, North Island, New Zealand): Implications for the rotation history of the Hikurangi margin, N. Z. J. Geol. Geophys., 48, 185-196.

Rowan, C. J., and A. P. Roberts (2008), Widespread remagnetizations and a new view of Neogene tectonic rotations within the Australia-Pacific plate boundary zone, New Zealand, J. Geophys. Res. 113, B03103, doi:10.1029/2006JB004594.

Song, T. R. A., and M. Simons (2003), Large trenchparallel gravity variations predict seismogenic behavior in subduction zones, Science, 301, 630-633, doi:10.1126/science. 1085557 .

Speden, I. G. (1975), Cretaceous stratigraphy of Raukumara Peninsula, part 1: Cretaceous stratigraphy of Koranga (parts N87 and N88; part 2: Geol- ogy of the Lower Waimana and Waiotahi valleys (part N78), N. Z. Geol. Surv. Bull., 91, 1-69.

Sporli, K. B., and Y. Aita (1994), Tectonic significance of Late Cretaceous radiolaria from the obducted Matakoa Volcanics, East Cape, North Island, New Zealand, Geosci. Rep. 20, pp. 115-133, Shizuoka Univ., Shizuoka, Japan.

Stoneley, R. (1968), A lower Tertiary decollement on the East Coast, North Island, New Zealand, $N . Z . J$ Geol. Geophys., 11, 128-156.

Strong, C. P. (1976), Cretaceous foraminifera from the Matakaoa Volcanic Group, N. Z. J. Geol. Geophys., $19,140-143$.

Strong, C. P. (1980), Early Paleogene foraminifera from Matakaoa Volcanic Group, N. Z. J. Geol. Geophys., 23, 267-272.

Sutherland, R. (1995), The Australia-Pacific boundary and Cenozoic plate motions in the SW Pacific; some constraints from Geosat data, Tectonics, 14 819-831, doi:10.1029/95TC00930.

Sutherland, R. (1999), Basement geology and tectonic development of the greater New Zealand region; an interpretation from regional magnetic data, Tecto nophysics, 308(3), 341-362, doi:10.1016/S0040 1951(99)00108-0.

Thornley, S. (1997), Neogene tectonics of Raukumara Peninsula, northern Hikurangi margin, New Zealand, $\mathrm{Ph} . \mathrm{D}$. thesis, Victoria Univ. of Wellington, Wellington, New Zealand.

Upton, P., P. O. Koons, and D. Eberhart-Phillips (2003), Extension and partitioning in an oblique subduction zone, New Zealand: Constraints from three-dimensional numerical modeling, Tectonics, 22(6), 1068, doi:10.1029/2002TC001431.

Uruski, C. I., B. D. Field, R. H. Funnell, C. J. Hollis, A. Nicol, and G. Maslen (2006), Developments in the central and northeastern East Coast Basin, North Island, New Zealand, APPEA J., 46, 215-235.

VonHuene, R., and D. W. Scholl (1991), Observations at convergent margins concerning sediment subduction, subduction erosion, and the growth of continental crust, Rev. Geophys., 29(3), 279-316, doi:10.1029/91RG00969.

Waight, T. E., S. D. Weaver, and R. J. Muir (1998), Mid-Cretaceous granitic magmatism during the transition from subduction to extension in southern New Zealand; a chemical and tectonic synthesis, Lithos, 45(1-4), 469-482, doi:10.1016/S00244937(98)00045-0

Walcott, R. I. (1986), The kinematics of the plate boundary zone through New Zealand: A comparison of short- and long-term deformations, Geophys. J. R. Astron. Soc., 79, 613-633.

Walcott, R. I. (1987), Geodetic strain and the deformational history of the North Island of New Zealand during the late Cainozoic, Philos. Trans. R. Soc London, Ser. A, 321, 163-181, doi:10.1098 rsta.1987.0009.
Walcott, R. I., T. C. Mumme, and D. A. Christoffel (1981), Bending within the axial tectonic belt of New Zealand in the last $9 \mathrm{Myr}$ from paleomagnetic data, Earth Planet. Sci. Lett., 52(2), 427-434, doi:10.1016/0012-821X(81)90195-3.

Wallace, L. M., J. Beavan, R. McCaffrey, and D. Darby (2004), Subduction zone coupling and tectonic block rotations in the North Island, New Zealand, J. Geophys. Res., 109, B12406, doi:10.1029/ 2004JB003241.

Wellman, H. W. (1959), Divisions of the New Zealand Cretaceous, Trans. R. Soc. N. Z., 87, 99-163.

Wells, R. E., R. J. Blakely, Y. Sugiyama, D. W. Scholl, and P. A. Dinterman (2003), Basin-centered asperities in great subduction zone earthquakes: A link between slip, subsidence, and subduction erosion?, J. Geophys. Res., 108(B10), 2507, doi:10.1029/ 2002JB002072.

Wilson, K., K. Berryman, U. Cochran, and T. Little (2007), Holocene coastal evolution and uplift mechanisms of the northeastern Raukumara Peninsula, North Island, New Zealand, Quat. Sci. Rev., 26, 1106-1128, doi:10.1016/j.quascirev.2007.01.005.

Wood, R., and B. Davy (1994), The Hikurangi Plateau, Mar. Geol., 118, 153-173, doi:10.1016/00253227(94)90118-X

Wood, R. A., G. Lamarche, R. H. Herzer, J. Delteil, and B. Davy (1996), Paleogene seafloor spreading in the southeast Tasman Sea, Tectonics, 15, 966-975, doi:10.1029/96TC00129.

Wright, I. C., L. M. Parson, and J. A. Gamble (1996) Evolution and interaction of migrating cross-arc volcanism and backarc rifting; an example from the southern Havre Trough $\left(35^{\circ} 20^{\prime}-37^{\circ} \mathrm{S}\right), J$. Geophys. Res., 101, 22,071-22,086, doi:10.1029/96JB01761.

Wright, I. C., T. J. Worthington, and J. A. Gamble (2006), New multibeam mapping and geochemistry of the $30^{\circ}-35^{\circ} \mathrm{S}$ sector, and overview, of southern Kermadec arc volcanism, J. Volcanol. Geotherm. Res., 149, 263-296, doi:10.1016/j.jvolgeores. 2005.03.021.

S. Bannister, D. Barker, F. Davey, B. Field, S. Henrys, V. Stagpoole, R. Sutherland, S. Toulmin, and C. Uruski, GNS Science, P.O. Box 30-368, Lower Hutt, New Zealand. (r.sutherland@gns.cri.nz)

D. Bassett and T. Stern, Environment and Earth Sciences, School of Geography, Victoria University of Wellington, P.O. Box 600, Wellington 6005, New Zealand.

E. R. Flueh, H. Kopp, and M. Scherwath, Leibniz Institute of Marine Sciences at University of Kie (IFM-GEOMAR), Wischhofstrasse 1-3, D-24148 Kiel, Germany.

C. Kennedy, New Zealand Ministry of Economic Development, P.O. Box 1473, Wellington, New Zealand. 